\title{
LEX
LOCALIS
}

\section{.................. \\ Evidence in Civil Law - Sweden}

\author{
Author:
}

Eric Bylander 


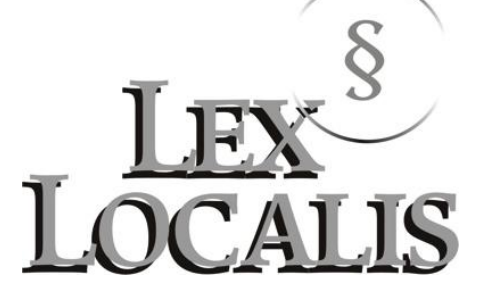




\section{(C) Institute for Local Self-Government and Public Procurement Maribor}

All rights reserved. No part of this book may be reprinted or reproduced or utilized in any form or by any electronic, mechanical, or other means, now known or hereafter invented, including photocopying and recording, or in any information storage or retriveal system, without permission in writing from the publisher.

Title: $\quad$ Evidence in Civil Law - Sweden

Author: Eric Bylander

First published 2015 by

Institute for Local Self-Government and Public Procurement Maribor

Grajska ulica 7, 2000 Maribor, Slovenia

www.lex-localis.press, info@lex-localis.press

Book Series: Law \& Society

Series Editor: Tomaž Keresteš

CIP - Kataložni zapis o publikaciji

Narodna in univerzitetna knjižnica, Ljubljana

$347(485)(0.034 .2)$

BYLANDER, Eric

Evidence in civil law - Sweden [Elektronski vir] / Eric Bylander. - El. knjiga. - Maribor : Institute for Local Self-Government and Public Procurement, 2015. - (Lex localis) (Book series Law \& society)

Način dostopa (URL): $\underline{\text { http://books.lex-localis.press/evidenceincivillaw/sweden }}$

ISBN 978-961-6842-60-0 (epub)

281132288

Price: free copy

This project has been funded with support from the European Commission. This publication reflects the views only of the authors, and the Commission cannot be held responsible for any use which may be made of the information contained therein.

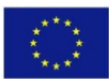

With the support of the Civil Justice Programme of the European Union 


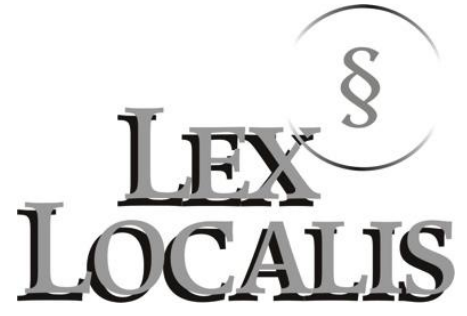

Evidence in Civil Law - Sweden

Eric Bylander 



\title{
Evidence in Civil Law - Sweden
}

\section{ERIC BYLANDER}

\begin{abstract}
This publication is based on the Swedish report to the project Dimensions of Evidence in Civil Procedure. The major objective of the project has been to explore whether there exists a common core of European Law of Evidence, and if it does, to describe its content and its most important points of discord among the national legal systems. By providing a clear picture of common core principles, the project can serve as a starting point for further harmonisation or unification processes in this field. A basic assumption of the project is that there can be no trust without a clear picture what courts do in matters of evidence, and how they discover the facts. This publication presents the relevant aspects of the Swedish legal system. The Swedish system for adjunction seldom takes its ground in firmly defined principles, but principles appear in decisions ad hoc. The Swedish application of the principle of free production of evidence and the principle of free assessment of evidence are far-reaching.
\end{abstract}

KEYWORDS: • evidence $\cdot$ civil procedure $・$ Sweden $・$ fundamental principles $\bullet$ burden of proof $\bullet$ written evidence $\bullet$ witnesses

CorResPondence AdDress: Eric Bylander, LL.D., Associate Professor, Uppsala University, Faculty of Law, P.O. 512, SE-751 20 Uppsala, Sweden, email: Eric.Bylander@jur.uu.se. 


\section{Eric Bylander, LL. D.}

Author Biography Eric Bylander, born in 1973, is Associate Professor (Docent) and Senior Lecturer of Procedural Law (Universitetslektor), and LL.D. (Jur. dr.), at the Faculty of Law, Uppsala University, Sweden. He is the Chairman of the Nordic Association of Procedural Law (Nordiska Föreningen för Processrätt, NFfP), and a Member of International Association of Procedural Law (IAPL). He has served as an Assistant Judge at courts of first instance, and as a court appointed mediator. 


\section{Foreword}

This publication is based on the Swedish report to the project Dimensions of evidence in civil procedure (Project DEECP: JUST/2011-2012/JCIV/AG/3434) with financial support from the Civil Justice/Criminal Justice Programme of the European Union. ${ }^{2}$ The major objective of the project has been to explore whether there exists a common core of European Law of Evidence (and taking evidence in particular), and if it does, to describe its content and its most important points of discord among the national legal systems. By providing a clear picture of common core principles, the project can serve as a starting point for further harmonisation or unification processes in this field. A basic assumption of the project is that there can be no trust without a clear picture what courts do in matters of evidence, and how they discover the facts.

I would like to thank my former assistant Emmy Falck, LL.M., and doctoral candidate Anna Waldenström for their valuable contributions to the underlying Swedish report.

Eric Bylander

${ }^{2}$ See the home page of the project, http://www.acj.si/en/presentation-evidence. 


Evidence in Civil Law - Sweden

E. Bylander

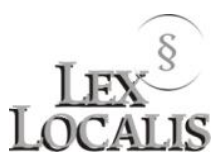

\section{Contents}

Part I ............................................................................................. 1

$1 \quad$ Fundamental Principles of Civil Procedure ............................................. 1

1.1 Principle of Free Disposition of the Parties and Officiality

Principle.

1.2 The Adversarial and the Inquisitorial Principle ....................................... 3

1.3 Hearing of Both Parties Principle (the Contradictory Principle) ............... 4

1.4 Principle of Orality .......................................................................... 6

1.5 The Principle of Directness.................................................................... 7

1.6 Principle of Public Hearing...................................................................... 7

1.7 Principle of Pre-trial Discovery ........................................................ 8

2 General Principles of Evidence Taking ........................................... 8

$2.1 \quad$ Free Assessment of Evidence ............................................................... 8

2.2 Relevance of Material Truth .................................................................. 9

$3 \quad$ Evidence in General........................................................................... 11

3.1 Value of Different Methods of Proof ................................................ 11

3.2 The Minimum Standard of Proof ............................................................ 12

3.3 Means of Proof .................................................................................... 12

3.4 Formally Prescribed Type of Evidence.............................................. 13

3.5 Proving the Existence of Rights Arising Out of a Cheque or Bill or Exchange ....................................................................................... 13

3.6 Duty for Parties to Produce or Deliver Evidence..................................... 14

3.7 Duty for Third Persons to Deliver Evidence......................................... 14

3.8 Value of Judicial and Administrative Decisions as Evidence................... 14

$4 \quad$ General Rule on the Burden of Proof....................................................... 14

4.1 Main Doctrine Behind Burden of the Proof Rules ................................... 14

4.2 Proof Standards.............................................................................. 14

4.3 Rules Which Exempts Certain Facts from the Burden of Proof .............. 15

4.4 Duty to Contest Specified Facts and Evidence ..................................... 15

4.5 The Doctrine of iura novit curia............................................................ 15

4.6 Obligations and Possibilities of the Courts ............................................ 15

4.7 Court-initiated Evidence Collecting in Civil Cases ................................. 16

4.8 Additional Submission of Evidence Allowed by the Court ...................... 16

4.9 Court Order Addressed to a Third Party Holding Evidence .................... 17

$5 \quad$ Written Evidence ............................................................................... 17

5.1 Concept of Documents in the Legal Sistem ......................................... 17

5.2 Other Documents for Which a Presumption of Correctness Exists ......... 18

5.3 Evidential Value of Public and Private Documents ................................ 18

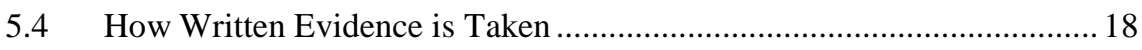

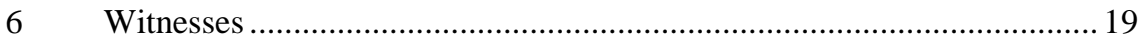

6.1 Obligation to Testify ............................................................................. 19

6.2 Witnesses are Summoned by Court ........................................................ 19 
ii | Contents

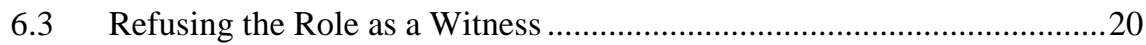

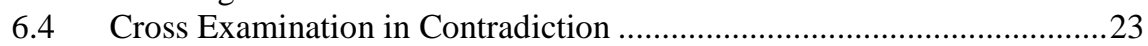

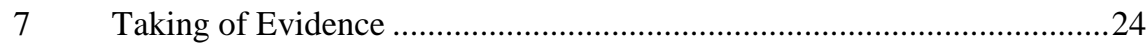

7.1 Sequence in Which Evidence has to be Taken .....................................24

7.2 Responsibility for Bringing the Evidence in Court ................................24

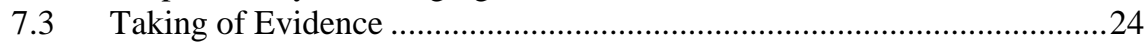

7.4 Rejection of an Application to Obtain Evidence ....................................25

7.5 The Hearing...............................................................................26

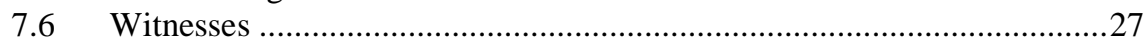

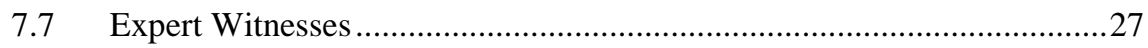

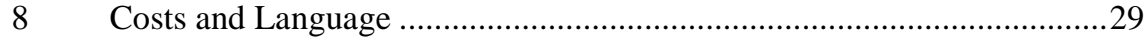

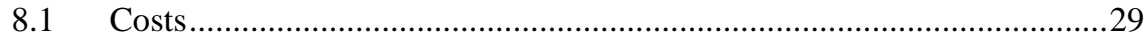

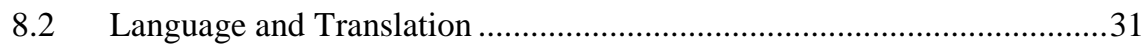

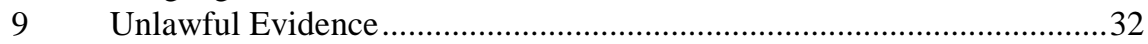

9.1 Distinction Between "Illegally Obtained Evidence" and "Illegal Evidence" ............................................................................................ 32

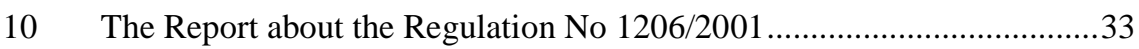

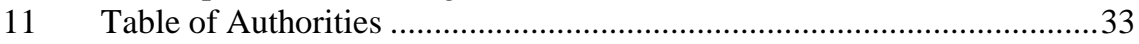

Part II - Synoptical Presentation ........................................................ 35

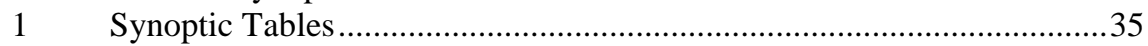

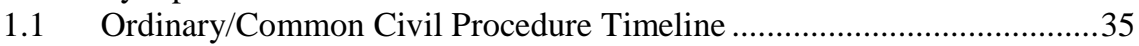

1.2 Functional Comparison .................................................................... 38

References ............................................................................ 41 
Evidence in Civil Law - Sweden

E. Bylander

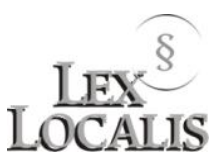

\section{Part I}

\section{Fundamental Principles of Civil Procedure}

The Swedish law of civil (as well as criminal) procedure is regulated in The Code of Judicial Procedure (1942:740), hereinafter the Code. ${ }^{3}$ The Code separates between matters amenable to out-of-court settlement (dispositiva tvistemål) and matters not amenable to out-of-court settlement (indispositiva tvistemål).

\subsection{Principle of Free Disposition of the Parties and Officiality Principle}

The principle of party disposition (in Swedish dispositionsprincipen) and the principle of the ex officio competence of the court (in Swedish officialprincipen) are two fundamental principles in the Swedish law of civil procedure.

These principles are not explicitly stated in the Code, but they are used in the legal doctrine, where they serve as a way to describe the party's possibilities to control the procedure. According to the principle of party disposition, the court may, in matters amenable to out-of-court settlement, undertake a procedural measure only in accordance with a claim by one or both of the parties. ${ }^{4}$ The principle of the ex officio competence of the court means that the court is obligated to undertake a procedural measure if the court finds it necessary for the process, regardless of the parties' request. In general the first principle applies in cases amenable to out-of-court settlement and the second in cases not amenable to such settlement.

In the Swedish law of civil procedure, the principle of parties' autonomy represents the gap between a complete principle of the ex officio competence of the court and a complete principle of the parties' disposition. In the legal doctrine, the principle has been described as the procedural actions that the parties may take within the procedure with a binding force to the court. ${ }^{5}$

It is forbidden to decide extra et petitum according to Chapter 17 Section 3 of the Code, which applies to both matters amenable to out-of-court settlement and matters not amenable to out-of-court settlement.

3 The Code, in its 1998 composition, can be downloaded in English from http://www.government.se/sb/d/390/a/1540.

${ }^{4}$ Ekelöf/Edelstam (2002), p. 58, and Lindell (2004), p. 30.

${ }^{5}$ Lindell (1988), p. 11. 
It should be noted, that the Swedish system for adjunction seldom takes its ground in firmly defined principles, but principles appear in decisions ad hoc. In Sweden, the application of principles is more practical than dogmatic, a way to apply principles which may be contrasted to the German legal system.

The possibility to introduce new facts and evidence is to a great amount depending on at which instance the question is raised. There is also a great difference between matters amenable to out-of-court settlement and matters not amenable to out-of-court settlement regarding the possibility to introduce new facts and evidence. Chapter 43 Section 10 of the Code regulates the preclusion that may occur at the main hearing, where the court may decide about preclusion if a party is delaying the process or otherwise does not run the process in a proper manner. The section states:

If, during the main hearing, a party amends a statement previously made by him, adds something thereto, or invokes circumstances or evidence that he has not mentioned prior to the commencement of the main hearing, that new material may be disregarded if it can be assumed that the party tries by his conduct to delay the trial or to surprise the opposing party or the party else acts in some other improper purpose or by gross carelessness.

Chapter 42 Section 15 of the Code and Chapter 42 Section 15 a of the Code regulates preclusion in matters amenable to out-of-court settlement in the lower court. Chapter 42 Section 15 of the Code states:

If the matter is amenable to out of court settlement, a party may be directed to finally determine his action or defence and to state the evidence that he invokes if it is required in view of how during the disposal of the case he previously has asserted his action. After expiration of the time for such a statement, the party may not allege any new circumstance or any new evidence unless he reasonably proves that he has had a valid excuse for failure previously to allege the circumstance or evidence.

Chapter 42 Section 15 a regulates the courts possibility to decide a time-limit for the preparation and the parties' possibility to refer to new evidence after that time-limit.

Within the court of Appeal, preclusion is regulated in Chapter 50 Section 25 third paragraph of the Code, regarding matters amenable to out-of-court settlement. The paragraph states:

As to cases where the matter at issue is amenable to out of court settlement, in the court of appeal a party may invoke in support of his position a circumstances or item of evidence not previously presented, only if

1. he shows probable cause for not having been able to invoke the circumstance or item of evidence in the district court, or

2. he otherwise has had a valid excuse for his failure to do that. 
For the Supreme Court, preclusion is regulated in Chapter 55 Section 13 of the Code, which regulates both matters amenable to out-of-court settlement and matters not amenable to out-of-court settlement. The article states:

In civil cases a party may assert in the Supreme Court in support of his action a circumstance or item of evidence which has not previously been presented only if he shows probable cause for not having been able to invoke the circumstance or item of evidence in a lower court or otherwise has a valid excuse for failing to do so. A set-off defence initially asserted in the Supreme Court may be dismissed unless it can be considered in the case without inconvenience.

The requirement regarding new evidence is tightened in the higher courts compared to the lower courts.

According to new legislation, see Chapter 35 Section 6 of the Code, the parties are fully responsible to submit evidence, with the exception for matters not amenable to out-ofcourt settlement.

\subsection{The Adversarial and the Inquisitorial Principle}

According to Chapter 35 Section 6 of the Code, the parties are in matters amenable to out-of-court settlement, responsible for collecting evidence material. Within matters not amenable to out-of-court settlement, the court may collect evidence material. The adversarial and inquisitorial principles are both part of the Swedish legal terminology. They are mainly used to classify different procedural systems.

The adversarial principle (in Swedish den kontradiktoriska principen) is defined as a two-party process with mainly oral proceedings ${ }^{6}$ and the inquisitorial principle (in Swedish den inkvisitoriska principen) is defined as where the court both investigates and adjudicates the case. ${ }^{7}$

Within the Swedish legal doctrine, the principle of negotiation (in Swedish förhandlingsprincipen) is also applied. The principle is applied in order to describe the activity that the parties may exercise within the process. ${ }^{8}$

The court is allowed to decide to take evidence only in matters not amenable to out-ofcourt settlement, according to Chapter 35 Section 6 of the Code.

The court may, according to the Swedish law of civil procedure, give the parties substantive (materiell) or procedural (formell) guidance during the main hearing. Procedural guidance has a great importance and is a debated subject within the legal doctrine. ${ }^{9}$ The substantive guiding is, regarding the preparation, regulated in Chapter 42

\footnotetext{
${ }^{6}$ Arbetsdomstolen [The Swedish Labour Court], AD 2004 nr 103.

${ }^{7}$ Ekelöf/Edelstam (2002), p. 70.

${ }^{8}$ Ekelöf/Edelstam (2002), p. 69.

${ }^{9}$ Lindell (1988), p. 13.
} 
Section 8 second paragraph of the Code: "During the preparation, the court shall proceed, depending upon the nature of the case, the issues in dispute to be elucidated and the parties to state everything that they wish to invoke in the case. By questions and observations the court shall attempt to remedy unclear and incomplete statements made by the parties". Regarding the main hearing, the substantive guiding is regulated in Chapter 43 Section 4 second paragraph of the Code: "The court shall also make certain that the case is investigated according to its nature and that irrelevant matters are not presented. Through questions and observations the court shall attempt to remedy any unclear and incomplete statement".

During the preparation of the main hearing, the court, according to Chapter 42 Section 16 of the Code, should prepare a written summary of the parties' claims and objections such as these are understood by the court, if it is of benefit for the disposal of the case. That Section may be combined with Chapter 42 Section 15 and Section 15 a, or Chapter 43 Section 10 of the Code, in which preclusion is regulated (see 1.1 above), to know which facts that have been referred to. However, preclusion does not automatically occur if a claim or an objection does not appear on the written summary. The consequence of preclusion is that the court will disregard the precluded facts or material.

\subsection{Hearing of Both Parties Principle (the Contradictory Principle)}

The contradictory principle (in Swedish kontradiktionsprincipen) is an existing principle in the Swedish civil procedure law, which has become more important since the ECHR was incorporated within the national Swedish legislation in 1995. It should be noted, that the Swedish system applies the term den kontradiktoriska principen also to describe the adversarial principle. ${ }^{10}$

The contradictory principle includes all decisions, and follows the definition that a defendant shall have the right to give one's opinion regarding all circumstances. It should be noted that the principle only results in a right, and not an obligation to give one's opinion. According to Chapter 42 Section 18 second paragraph of the Code, the parties shall be given an opportunity to give one's opinion before the court concludes a decision. See for example in case law, NJA 1980 p. 635, where the Supreme Court quashed a decision from the District Court because one party had been conferred compensation for litigation costs without the adverse party had been notified about the claim.

The limitation of the parties' opportunity to undertake preparatory acts can be deducted from Chapter 35 Section 7 of the Code, which states the limitations for the parties to submit evidence, and states in which situations the court may dismiss evidence. Chapter 35 Section 7 of the Code states:

${ }^{10}$ Ekelöf/Edelstam (2002), p. 70. 
The court may also reject an item of evidence offered:

1. if the circumstance that a party offers to prove is without importance in the case,

2. if the item of evidence offered is unnecessary,

3. if the item of evidence offered evidently should be of no effect,

4. if the item of evidence offered can be presented in another way with considerably less trouble or costs,

5. if the item of evidence offered cannot be presented in spite of reasonable efforts and the court's judgment or decision should not be delayed any longer.

It should be noted that the courts have developed a highly permissive attitude.

The parties have a right to be present during the taking of all evidence and the parties also have a right to be heard about the assessment of the evidence. Though, when the deliberation is written, the parties do not participate. Most of the time, the deliberation is held in camera.

The general rule is that a case is determined after a main hearing; see for example Chapter 42 Section 18 of the Code. This can be compared to Chapter 43 Section 2 of the Code where it is regulated who shall be present at the main hearing and what the consequences are if the parties are absent. If any of the parties is absent, the main hearing shall be cancelled or scheduled to a new date. Chapter 44 of the Code regulates parties' absents.

The right for the parties to be heard is an underlying principle, which is expressed in individual rules in the Code. The principle has certain exceptions, for example if the plaintiff's statement does not constitute a legal basis for the case or if it is otherwise clear that the case is unfounded, see Chapter 42 Section 5 first paragraph of the Code. If this situation occurs, the court does not issue a summons. Another example of an exception from the principle is the possibility for the court to immediately impose a security measure to remain effective until otherwise ordered, if delay places the applicant's claim at risk.

Regarding preclusion, as an exception from the contradictory principle is Chapter 35 Section 7 of the Code applicable, when the court dismisses evidence. It is then not necessary for the court to hear the adverse party.

If the right for a party to be heard is violated, the consequence may constitute a procedural error with the consequence that a higher court sets aside the lower court's decision. Those consequences are regulated either in Chapter 50 Section 28 of the Code or Chapter 59 Section 1 of the Code, depending on if the situation occurs before or after the judgment has been declared legally binding.

The principle of equal treatment (in Swedish likabehandlingsprincipen) is an overall principle in the Swedish legal system and is regulated in Chapter 1 Section 9, the 
Instrument of Government. ${ }^{11}$ In the statement, it can be read out that the courts, administrative authorities and others performing public administrative functions in its work shall include everybody's equality before the law and observe objectivity and impartiality.

If a party is absent from the procedure in a matter amenable to out-of-court settlement, a default judgment may be entered into by the court against the party missing, according to Chapter 44 Section 2 of the Code. A further consequence that may occur is a penalty of fine according to Chapter 44 Section 5 of the Code. According to Chapter 44 Section 1 of the Code and Chapter 44 Section 3 of the Code, the court may remove the case from the court's list if one or both of the parties are absent. There is also a possibility for the court to determine a case despite of the parties' absence, see Chapter 44 Section 7 of the Code. A default judgment according to Chapter 44 Section 7 a of the Code may also occur if the defendant fails to obey a directive to submit a written answer.

\subsection{Principle of Orality}

The principle of oral proceeding (in Swedish muntlighetsprincipen) is one of the leading principles in the Swedish law of civil procedure. It is also called the principle of oral testimony in the Swedish legal doctrine. ${ }^{12}$ The principle of concentration ${ }^{13}$ and the principle of immediateness are the two other fundamental principles for the trial proceedings according to the Code. These principles shall be applied in all instances. ${ }^{14}$ The principle of oral proceedings means that the court shall base its decision only on the facts that have been presented orally during the proceeding. The principle aims to create the best possible opportunities for the implementation of the principle of free assessment of evidence and especially the evaluation of evidence. Exception can be made, see for example Chapter 43 Section 5 of the Code, where it is stated that the parties may submit or read out written submissions and other written statements only if the court finds that it would facilitate the understanding of a statement or otherwise assist the proceedings. What has been stated during the preparatory proceedings may also be read out, if the statement that the party is presenting is divergent from the statement that the party did present during the preparatory proceedings, if the party refuse to speak or if there is any other special reasons.

Within the civil and criminal procedural law, the principle of oral proceeding is dominating, but written element has nevertheless a major role for the preparations before the main hearing. A trial is for example always initiated in written form. To be noted, within the administrative judicial procedure the situation is reverse and the main principle is written form, according to Section 9 the Administrative Court Procedure Act. $^{15}$

\footnotetext{
${ }^{11}$ Regeringsformen (1974:152).

${ }^{12}$ Lindell (1988), p. 32.

${ }^{13}$ The principle of concentration means that the proceedings shall be as concentrated as possible; see Chapter 46 Section 11 of the Code.

${ }^{14}$ Lindell (2012), p. 118.

${ }^{15}$ Förvaltningsprocesslagen (1971:291).
} 


\subsection{The Principle of Directness}

In Swedish civil procedure law the principle of directness (In Swedish omedelbarhetsprincipen) is a valid principle, which is also named the principle of immediateness. The principle creates, as mentioned above, together with the principle of oral proceeding and the principle of concentration, the fundamental principles of the judicial process. The principle of directness is expressed in Chapter 17 Section 2 first paragraph of the Code and implies that the judgment shall be based only on the facts that have been directly presented at the proceeding. To be noted, Chapter 17 Section 2 first paragraph of the Code does not define the principle, the rule only states the consequence of the principle. In the legal doctrine, the principle has been described as that only the material that has been presented during the main proceeding may ground the decision by the court. The principle is divided into two parts, which includes that evidence shall be presented in its best form (which is considered to be orally according to Chapter 36 Section 16 of the Code) and also through the parties' appearance in person. The principle applies to what the judgment shall be based on. ${ }^{16}$

There are exceptions to the principle. In higher courts, the main rule is that oral evidence is presented by video recordings from the lower courts which are played during the proceedings. The way to use modern technology within the trial has been a part of a major reform within the Swedish judicial system entered into force in 2008 . The reform included a modernisation of the legal proceeding in general courts and changed several of the procedural rules in the Code. The aim of the reform was to create a modern system of judicial procedural that meets the requirements for legally secure, efficient and effective processing of cases and matters. ${ }^{17}$

It is a normal procedure for the appellate court to take evidence, and the appellate court is also allowed to evaluate evidence.

\subsection{Principle of Public Hearing}

The main rule in the Swedish law of civil procedure is that anyone is allowed to be present and take part of a court hearing, according to Chapter 5 Section 1 of the Code and Chapter 2 Section 11 of the Instrument of Government.

The principle of public hearing ${ }^{18}$ applies to court hearings and the hearings that the parties are directed to appear to. The writings in a proceeding are also public as a result of the Swedish principle regarding public access to public records.

The principle of public hearing is not defined in the Code but has been given the meaning in legal doctrine that the main rule is that court hearings are open to the public for them to be present at and take part of. ${ }^{19}$

\footnotetext{
${ }^{16}$ Lindell (1988), p. 32.

${ }^{17}$ SOU 2012:93, p $17 \mathrm{ff}$.

${ }^{18}$ Or principle of publicity according to Lindell (1988), p. 31.

${ }^{19}$ Edelstam (2001), p. 25.
} 
When a court hearing is open to the public the press and other media are free to be present and report from the hearing. However, photographs etc. must not be taken in the courtroom. Video recordings are for the use of the courts only. According to Chapter 5 Section 9 second paragraph of the Code the court may prohibit sound recording or transmitting of an examination by phonetic means, if it appears that the recording will so embarrass the person being heard as to be detrimental to the inquiry.

The exceptions to the principle of public hearing are stated in Chapter 5 Section 2 of the Code and Chapter 5 Section 1 second to fourth paragraph of the Code. The exceptions apply to cases of extraordinary importance, for example when underage or mentally disturbed persons are involved.

\subsection{Principle of Pre-trial Discovery}

The principle of pre-trial discovery does not exist in the Swedish law of civil procedure. Reservation of evidence, evidence tracing and acquisition of evidence are though permitted.

In conclusion, it may be added that principles as such, have a subordinated role in the Swedish law of civil procedure. To be noted are the principles of legality and delegation. These are in close relation to the above-mentioned principles of party disposition and the ex officio competence of the court which gives the parties the right to control the judicial process. The principles are not normatively decisive, but are used more in a descriptive way.

\section{General Principles of Evidence Taking}

\subsection{Free Assessment of Evidence}

The principle of free assessment of evidence is a valid principle in the Swedish law of civil procedure, including both production of evidence and evaluation of evidence and is stated in Chapter 35 Section 1 of the Code. It follows from that section that the court shall take into account everything that has occurred in accordance with the dictates of its conscience and after that determine what has been proved in the case. The principle have existed in the Code since 1948 but prior to that year developed in case law. ${ }^{20}$

Regarding if the courts are bound by the party's disposition, the parties cannot conclude an agreement about a certain fact to be given a certain evidential value. In matters amenable to out-of-court settlement, the parties are however allowed to agree that a certain fact does not have to be proved. This is according to Chapter 35 Section 3 of the Code stating: "If, in a case amenable to out of court settlement, a party admits a certain circumstances, his admission constitutes full proof against him."

${ }^{20}$ Lindell (2012), p. 116. 
The court has the right to evaluate the evidence as long as the parties have not agreed about the existence of a certain fact, see Chapter 35 Section 1 of the Code and Chapter 35 Section 3 of the Code.

The court is, according to Chapter 35 Section 1 of the Code, bound to make an evaluation "dictates of its conscience" (in Swedish en samvetsgrann prövning). This is a sort of standard for the courts' evaluation, which means that the evaluation cannot be based on the individual opinion of one judge but has to be in accordance with the general opinion of the court and be acceptable to other reasonable individuals. ${ }^{21}$

This necessary condition has been developed in the legislative history, case law and legal doctrine. However, the question has received most attention regarding criminal procedure. $^{22}$

The Swedish law of civil procedure has only a small number of formal rules to regulate assessment of evidence. It is stated in Chapter 35 Section 1 second paragraph of the Code "as to the effect of certain kinds of evidence, the specific provisions thereon shall govern". ${ }^{23}$ This statement opens up for an impact of, for example EU-legal instruments, regarding these questions.

The principle of free assessment of evidence implies that no limitation is stated in the law regarding the knowledge resources that may be used to find out the truth and also that the court, when evaluating the evidence, is not bound by legal rules; see below. ${ }^{24}$

\subsection{Relevance of Material Truth}

The Swedish system has a principle of material truth, although the principle is applied within the limitations regarding the principles discussed above. The courts responsibility concerning the material truth is regulated in Chapter 42 Section 8 second paragraph of the Code and Chapter 43 Section 4 second paragraph of the Code; see the discussion above.

The principle of material truth is most dominant in cases where a third party may be affected and the parties are therefore not entirely free to conclude agreements out of court. However, during the evaluation of evidence, the principle of material truth is a guiding principle in all cases. Within matters not amenable to out-of-court settlement, where the court may apply its ex officio competence to inherent evidence, the material truth will sought to be clarified to a greater extent. This compared to matters amenable to out-of-court settlement, where the court only forms its decision from the facts that the parties have presented. ${ }^{25}$

\footnotetext{
${ }^{21}$ Lindell (2012), p. 195.

${ }^{22}$ See NJA II 1943 p. 444 , where the standard comes to an implicit expression.

${ }^{23}$ For example, this regards agricultural lease; see Chapter 9 Section 28 of The Land Code (Jordabalken, 1970:994); see further 5.2 below.

${ }^{24}$ NJA II 1943 p. 444.

${ }^{25}$ Lindell (2012), p. 46.
} 
Regarding matters amenable to out-of-court settlement, the principle does not have a major importance. Though, the principle of free assessment of evidence is of principle held, which is meant to guarantee a certain measure of material truth.

There are only a few limitations within establishing the material truth. One example is the limitation within the obligation to give evidence according to Chapter 36 Section 5 of the Code and Chapter 36 Section 6 of the Code, which concerns secrecy within a certain circle of officials and relatives. There is also a limitation regarding the obligation to produce a written communication according to Chapter 38 Section 2 of the Code:

Anybody holding a written document that can be assumed to be of importance as evidence is obliged to produce it; in criminal cases, however, such an obligation is not imposed upon the suspect or any person related to him as stated in Chapter 36, Section 3.

Neither a party, nor any person related to him as stated above, is obliged to produce written communications between the party and such a related person or between such related persons. Neither a public official nor any other person referred to in Chapter 36, Section 5, may produce a written document if it can be assumed that its contents is such that he may not be heard as a witness thereto; when the document is held by the party for whose benefit an obligation of confidentiality is imposed, that party is not obliged to produce the document. The provision in Chapter 36, Section 6, as to the privilege of a witness to refuse to testify shall correspondingly apply to the holder of a written document if the content of the document is such as referred to in the said Section.

The obligation to produce written documents does not extend to jottings or any other like personal notes prepared exclusively for one's private use unless extraordinary reason exists for their production.

In addition, there are also limitations within the selection of evidence.

Regarding provisions allowing for determination of the material, there is in the Swedish law of civil procedure a general obligation to give evidence, which is stated in various sections in Chapter 36 of the Code. There is no general obligation to be an expert witness, see Chapter 40 Section 4 of the Code. According to Chapter 38 Section 3 of the Code, there is however an obligation to produce a written communication as evidence, and there is also an obligation to provide an object for inspection for view, see Chapter 39 Section 5 of the Code.

The Swedish system regulates a limitation of the right to propose new facts and evidence, see the discussion about preclusion above.

The standards regarding material truth within the civil procedure law can be compared to the criminal procedural law, where the material truth has its strongest impact. According to the general perception, the Swedish system states a requirement that a fact 
shall be set behind a reasonable doubt to base the court's decision. Regarding matters amenable to out-of-court settlement, there is a lower requirement stated which normally is expressed by that a fact shall be verified. To be noted is that the standard of proof varies between different types of cases.

In conclusion, there are no other general principles than the ones explained in chapter 1 and 2 above.

\section{$3 \quad$ Evidence in General}

\subsection{Value of Different Methods of Proof}

The court will typically consider certain types of evidence to be of greater value than other types of evidence. However, this is not stated in law but emerges in principles and in case law. For example, a private document may be given a greater value, which is a logical persuasiveness.

Statement of a witness given under oath is regarded as strong evidence, while information given by the parties and others who are close to the case and who are not under an oath, is regarded as weaker evidence. A document where the authenticity has not been questioned is often given a high value as evidence. ${ }^{26}$

There are no means of evidence, which can be applied or presented only after the modes of proof required by law become impossible. A possibility for the court to reject evidence is for example stated in Chapter 35 Section 7 (4) of the Code, which is a way for the court to influence which means of evidence that is applied, based on the courts, preference. Chapter 35 Section 7 (4) of the Code states that the court may reject an item of evidence offered if the item of evidence offered can be presented in another way with considerably less trouble or costs.

In exceptional cases, certain methods of proof are obligatory. One example of the situation where certain proof is obligatory regards the testator's wishes where a will is an obligatory method of proof. See Chapter 35 Section 1 second paragraph of the Code, which states that no proof is required for facts that are generally known, nor is proof required as to legal rules.

One example of certain types of procedure where the facts in principle are proven by certain methods of proof is the content of public records, which naturally, almost is exclusively proved through written extracts from it. Form prescribed by law, in the material law, can also state that written proof is the exclusively (or almost exclusively) proof of importance. This regards for example purchase of real estate.

${ }^{26}$ Bylander/Andersson (2007), p. 15. 


\subsection{The Minimum Standard of Proof}

The minimum standard of proof in Sweden is probable cause (in Swedish sannolika $s k a ̈ l)$ and may be enough to obtain permission of provisional attachment and similar civil procedural coercive measures, see for example Chapter 15 Section 1 of the Code. There is a possibility for an even lower minimum standard of proof (compared to verified, in Swedish styrkt), which may be applied in cases where evidential difficulties occur or when there is an aim to protect a weaker party, for example a consumer.

\subsection{Means of Proof}

Means of proof (or means of evidence) are provided in the Swedish law of civil procedure; see Chapter 36-40 of the Code. The means of proof are witnesses, examinations of parties and of aggrieved persons not being a party, written evidence, views and experts.

The principle of numerus clausus does not apply in the Swedish system. There are means of proof that are not listed in the above-mentioned chapters but are still permitted, since anything that may affect the value of the evidence is permitted. ${ }^{27}$

No certain means of proof is excluded to be a possible means of proof, though, according to Chapter 35 Section 7 (3) of the Code, an item of evidence may be rejected by the court if the court finds that the item of evidence offered evidently should be of no effect.

In the Swedish system, parties' statements count as evidence. There are no constraints to parties' capability of testifying. Factors such as if the party is underage or suffers from disabilities may, however, have an impact on the evaluation of the evidence.

Both the party and the adversary party may ask for a party testimony, cf. Chapter 37 Section 2 of the Code. As mentioned above, the court is not allowed to request evidence in matters amenable to out-of-court settlement. This possibility belongs to the parties only.

There are limits to the possible objects of proof, which are corresponding to the regulations regarding witnesses. The limits are stated in Chapter 37 Section 3 of the Code which refers to Chapter 36 of the Code on witnesses. The limitations include, for example, people in their profession.

In principle a party cannot refuse to testify, but there are no coercive measures stated in the Code corresponding to those regarding witnesses. Refusal can however have a negative effect for the party during the evidential evaluation, see Chapter 35 Section 4 of the Code where it is stated "If a party fails to respond to a court directive to appear before it or else to perform any other act in the proceedings or refuses to answer a

${ }^{27}$ Ekelöf/Bohman (1992), p. 243. 
question relevant to the inquiry, the court shall determine, in view of all the attending circumstances, the evidentiary value of the party's behaviour".

In a matter amenable to out-of-court settlement, a party can give testimony under the affirmation of truth; see Chapter 37 Section 2 of the Code, with certain restrictions. An affirmation of truth is partly different from an oath, for example regarding the possibilities for penalty. The penalty for perjury is stated in Chapter 15 Section 1-4 The Penal Code. ${ }^{28}$ Chapter 15 Section 2 of the Penal Code states untrue statement of a party which may result in a maximum of two years of imprisonment or if the crime is petty, a fine or imprisonment of maximum six months, which is lower than the penalty for perjury, stated in Chapter 15 Section 1 of the Penal Code.

If a party is questioned under affirmation of truth incorrect information or information, which has been left out, may result in criminal liability for the party. Admissible grounds during a question under affirmation of truth correspond to what applies for witnesses. This is regulated in Chapter 37 Section 3, which refers to inter alia Chapter 36 Section 6 of the Code, where it is stated that close family members are excluded from the obligation to testify. If a party refuses to testify, the court will evaluate the legality of such a claim.

If a refusal to testify is considered unlawful, criminal liability may occur. If a lower court has allowed a party to refuse to testify, a higher court may quash the decision as the decision would construct a procedural error.

There are no specific rules for evaluating evidence gathered trough parties' testimony. Certain starting points are established practice, for example, an examination under the affirmation of truth is typically worth more than an examination without affirmation of truth.

\subsection{Formally Prescribed Type of Evidence}

As discussed above, as a main rule it is not necessary for certain facts to be proven by a formally prescribed type of evidence. There are, however, exceptions for a limited number of certain facts to be proven by formally prescribed types of evidence, for example confession in a matter amenable to out-of-court settlement, see Chapter 35 Section 1 second paragraph of the Code.

\subsection{Proving the Existence of Rights Arising Out of a Cheque or Bill or Exchange}

Regarding rights arising out of a cheque or a bill of exchange, the use of such documents has decreased sharply in Sweden. Proving the existence of rights arising out of like this may be proven by other means than presentation of the document in question. According to Chapter 44 Section $7 \mathrm{~b}$ of the Code, it would, though, probably

${ }^{28}$ Brottsbalken (1962:700). 
be evidential favourably to present the original document, in order to prove for example the underlying claim.

\subsection{Duty for Parties to Produce or Deliver Evidence}

There is no obligation to produce evidence in the Swedish law of civil procedure. However, if a party does not produce the evidence that the party is obligated to produce in order to win the case, the party risks having its claim dismissed. In exceptional cases, a party who against better knowledge, commence or causes the commencement of a civil action (for example without evidence) can be judged to fine, see Chapter 9 Section 1 of the Code.

\subsection{Duty for Third Persons to Deliver Evidence}

For third party, though, there is a duty to deliver evidence, namely regarding documents and objects for inspection, as discussed above. The consequences for breach that may occur are a fine according to Chapter 38 Section 5 of the Code and Chapter 39 Section 5 second paragraph of the Code or that the Enforcement Agency takes action.

\subsection{Value of Judicial and Administrative Decisions as Evidence}

The value of judicial and administrative decisions as evidence is not stated in law but they are generally considered to have a great value as evidence.

\section{General Rule on the Burden of Proof}

\subsection{Main Doctrine Behind Burden of the Proof Rules}

In the Swedish system, the burden of proof is of importance in such cases when the party who carries the burden of proof does not succeed to fulfil the demand of evidence, which is demanded. The referred claim is therefore not considered proved. The doctrine behind the burden of proof represents the pragmatism that characterizes the Swedish system generally. If the burden of proof for a specific situation is not regulated in the law, an assessment is made with regard to general principles from the legal doctrine. ${ }^{29}$

\subsection{Proof Standards}

The proof standard in the Swedish system differs a lot between different fields. In the legal doctrine, the proof standards have been exemplified with a figure, illustrating to which extend a dispositive fact is considered to exist. The highest proof standard of a dispositive fact that can be required is "certain", which with other words means that the dispositive fact is absolutely proven to exist. The line continues with the standards; clear, verified/shown, probable and presumably. After presumably, the list turns to count the same criteria, starting with presumably, but towards if a dispositive fact is

${ }^{29}$ Ekelöf/Edelstam/ (2009), p. 95. 
considered not to exist. It can for example be verified that a dispositive fact does not exist. $^{30}$

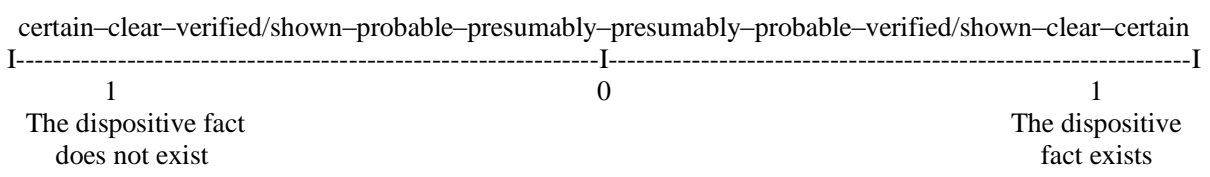

\subsection{Rules Which Exempts Certain Facts from the Burden of Proof}

There are rules in the Swedish legal system, which excludes certain facts from the burden of proof. One example is recognized facts according to Chapter 35 Section 2 of the Code.

\subsection{Duty to Contest Specified Facts and Evidence}

Regarding civil procedural cases (to be noted is that criminal cases differ greatly) the situation when a party refuses to answer a question is regulated in Chapter 35 Section 4 of the Code. If a summons is issued, a preparation shall take place. The object of the preparation is for instance to elucidate to what extent the parties differ about the facts alleged by them, see Chapter 42 Section 6 (2) of the Code. A party who is not willing to contribute to such elucidating may suffer from litigation costs. It is discussed in the legal doctrine if such behaviour can have an effect on the evidential evaluation.

\subsection{The Doctrine of iura novit curia}

In Chapter 35 Section 2 second paragraph first sentence of the Code, the doctrine of iura novit curia is expressed, as it is stated that no proof is required to legal rules. The parties are therefore not required to submit arguments regarding established law; however they are free to do so. Regarding foreign law, the court can, however, request the parties to present evidence regarding legal rules.

\subsection{Obligations and Possibilities of the Courts}

It is a highly debated issue if the court is obligated to advise the party if the facts claimed by the party and the proposed evidence is incomplete. In cases concerning small amounts where the parties are considered to manage without attorney, there may be such an obligation for the court. The obligation for the court regarding directions of proceeding within substantive law is regulated in Chapter 42 Section 8 second paragraph of the Code. The court may be required to provide this information also in writing, see Chapter 42 Section 9 of the Code where it is stated:

The preparation is effected at sessions, or by exchange of writings, or by other procedure. If appropriate, different forms of preparation may be combined.

${ }^{30}$ Ekelöf/Edelstam/ (2009), p. 200. 
The answer pursuant to Section 7 shall be provided in writing, unless considering the nature of the case it is more appropriate to deliver the answer at a session.

When a written answer has been filed with the court, a session shall be held as soon as possible unless, considering the nature of the case, a continued exchange of writings is more appropriate.

If a session is held, the preparation shall be finalized, if possible, at that session. If this cannot be done, the preparation shall continue by exchange of writings or at a new session.

The court is not expected to propose to the parties and other participants in a proceeding that they are to submit additional evidence. According to Chapter 35 Section 6 of the Code, the court is not allowed to obtain evidence on its own behalf within matters amenable to out-of-court settlement. Regarding matters not amenable to out-of-court settlement, the court is thus allowed to submit additional evidence, a possibility that shall be applied restrictively. If the court has the possibility to submit evidence, it is possible under the whole procedure, but it should be done as early as possible.

Chapter 35 Section 4 of the Code regulates the situation when a party fails to perform an act under the proceeding, and the behaviour may affect the assessment of the evidence. In Chapter 35 Section 4 of the Code it is stated:

If a party fails to respond to a court directive to appear before it or else to perform any other act in the proceedings or refuses to answer a question relevant to the inquiry, the court shall determine, in view of all the attending circumstances, the evidentiary value of the party's behaviour.

\subsection{Court-initiated Evidence Collecting in Civil Cases}

The possibility for the court to collect evidence on its own initiative has been discussed above. The obligation differs between matters amenable to out-of-court settlement and matters not amenable to out-of-court settlement. In matters amenable to out-of-court settlement, the court is not allowed to submit evidence according to Chapter 35 Section 6 of the Code. The obligation for the court to collect evidence in non-dispositive cases is limited to e.g. protection of the public interest or in family matters. The court is allowed, if necessary, to submit evidence in order to satisfy third party's interest. Cases regarding family matters are a typical example for when the court may collect evidence.

\subsection{Additional Submission of Evidence Allowed by the Court}

If during the presentation of evidence new facts that were previously not raised by parties become known, may a he court may also allow additional submissions of evidence. Additional submission of evidence shall be done as soon as possible. The rules regarding preclusion do not affect the procedure if the parties have showed enough 
care during the investigation. If the new facts were actually known by one of the parties, that party may be reliable for the litigation costs.

\subsection{Court Order Addressed to a Third Party Holding Evidence}

As discussed above, a party who is charged with the burden of proof and not in possession of certain evidence is allowed to ask the court to issue an order addressed to a third party holding that evidence to make it available.

\section{$5 \quad$ Written Evidence}

\subsection{Concept of Documents in the Legal Sistem}

Regarding the concept of document, there is no uniform document system in the Swedish system. For example, the right of insight to official documents is regulated in a specific way compared to the procedural rules that regulates the possibility to access documents and evidence. Written evidence is particularly regulated regarding means of proof. No decisive difference does thus occur with regard to the special regulation; see Chapter 38 of the Code and 39 of the Code. To be noted is that forgery of document can apply also to other documents than written ones, se Chapter 14 Section 1 of the Code.

There is no form prescribed by law, which is generally applicable regarding documents. Generally, most of the electronic documents are recognized. When it is stated a requirement in provision of personal signature, a document cannot be handed in electronically.

The probative value of electronic documents is not regulated on a comprehensive level. They are evaluated according to the principle of free evaluation of evidence; see 2.1 above. An electronic version of a document is not generally considered to be equivalent to a document, as discussed above.

In Sweden, a common applied system for electronic signatures and identification is named E-identification (in Swedish E-legitimation), which is also used by many authorities, for example the Tax Authority. The E-legitimation is, as a starting point, considered to be equal to an ordinary signature. In the specific case, the probative value is decided according to the principle of free evaluation of evidence; see 2.1 above.

Since the Swedish system applies the principle about free production of evidence, other ways to produce evidence or other objects may in the specific case have as great evidential value as written evidence.

What the other objects probative value is cannot be answered, as it is determined in the specific case. 


\subsection{Other Documents for Which a Presumption of Correctness Exists}

In practice there are documents (cf. 5.1 above) for which a presumption of correctness exists. However, this is not specified in the law. The presumption applies to documents issued by Swedish Authorities. ${ }^{31}$ These documents can be contested in any effective form.

There are very limited cases of exclusive means of proof, where the above-mentioned document alone can form the base of a judgment. One example is stated in Chapter 9 of Jordabalken (1970:994; the Land Code). According to Section 28 a certain kind of inspection at taking property in possession or leaving property under agricultural lease is an exclusive means of proof. This is an outflow of Chapter 35 Section 1 paragraph 2 of the Code, that the principle of free assessment of evidence can be set-aside by specific statements.

The weight of private documents as evidence is decided in the specific case as Sweden applies the principle of free assessment of evidence.

There are different categories of private documents in the perspective of evidence. Private documents will in cases when a written document is required, for example purchase of real estate and as a main rule regarding wills (where a witnessing in certain order is required), be regarded as a stronger evidence.

If such documents are contested by the other part, the authenticity can be questioned. The authenticity then has to be proved with the requested evidence in the specific case.

\subsection{Evidential Value of Public and Private Documents}

The procedural law does not draw any distinction between the evidential value of public and private documents. Though regarding falsification of documents, the action to falsify a public document can result in a higher penalty compared to a private, see Chapter 14 Section 1 and 3 of the Penal Code.

\subsection{How Written Evidence is Taken}

The main rule is that a hearing shall be oral and that written evidence shall be read out loud, according to Chapter 43 Section 5 of the Code. Evidence can be presented by referencing to written documents only if the court finds is appropriate, see Chapter 43 Section 8 third paragraph of the Code.

The court may force someone to produce evidence according to Chapter 38 Section 4 of the Code, which states: "when somebody is obliged to produce a written document as evidence, the court may order him to produce it. The person against whom the order should be addressed shall be afforded an opportunity to state his views."

${ }^{31}$ Bylander/Andersson (2007), p. 15. 
There is an obligation for the parties to produce evidence, within the limitation stated in Chapter 38 Section 2 of the Code, which corresponds to the limitations within the obligations to give evidence as a witness and have been discussed above.

The main rule is, according to Chapter 38 Section 1 of the Code: "Written documents invoked as evidence should be produced in the original. A certified copy may be produced if this is found sufficient or if the original is not obtainable." To be noted, the evidence "should" be presented in its original form, which refers to the principle of free assessment of evidence.

\section{$6 \quad$ Witnesses}

\subsection{Obligation to Testify}

Witnesses are as a main rule obligated to testify. The obligation to testify is part of a wider "obligation to produce evidence". There are, though, exceptions to the rule.

\subsection{Witnesses are Summoned by Court}

In the proceeding, the witnesses are summoned by the court. A witness may refuse to testify but must still appear in court. The party who that has referred to the witness shall be informed about the refusal and may thereby recall the witness, see Chapter 36 Section 7 of the Code.

There is no discretion of the court to decide upon the question if a witness refuses to testify. The interested party may contest such a refusal and the interested party can also give its opinion for the court to consider. If the court permits the refusal, the decision may be appealed, but only together with the appeal of the final judgment in the case.

According to Chapter 36 Section 1 of the Code, a starting point is that "everyone who is not a party in the case may be heard as a witness". The limitations to the statement include for example the aggrieved person in criminal cases. According to Chapter 36 Section 4 of the Code, the court shall "if testimony is sought from a person who is under the age of fifteen years or suffers from mental disturbance, the court shall determine in accordance with the circumstances whether he may be heard as a witness." There is a difference between being unfit to testify and the possibility for a witness to refuse to testify. If a person who is deemed to be unfit as a witness is summoned in court, he can refuse to give his opinion.

There is a privilege against self-incrimination in the Swedish system. Regarding civil procedural law and witnesses is Chapter 36 Section 6 first paragraph of the Code applicable where it states that "A witness may decline to testify concerning a circumstance that should reveal that he or a person related to him as stated in [Chapter 36] Section 3, has committed a criminal or dishonourable act." 


\subsection{Refusing the Role as a Witness}

The witnesses can refuse to give evidence. Regarding civil cases, it is stated in Chapter 36 Section 3 of the Code that close family is excluded from the obligation to give evidence. In some cases, the witnesses are allowed to refuse to give evidence with respect to secrecy, according to Chapter 36 Section 5 of the Code. Also some professionals can refuse to give evidence, for example lawyers, medical doctors, dentists and nurses. As mentioned above, a witness can also refuse to give evidence with regard to self-incrimination. These cases are enumerated in law and have been specified in case law.

The court has a limited discretion in assessing the grounds for refusal. The general obligations and limitations are stated in law.

No one can refuse to give evidence on basis of his or her personal status in general. Only in cases where information has been entrusted them in their profession, the witnesses can refuse to give evidence. For example, a medical doctor may not refuse to give evidence on basis of his profession, he may however refuse to testify concerning matters entrusted to, or found out by, him in his professional capacity.

A wide range of secrets are recognized in the Swedish system and can affect the taking of evidence, according to the Public Access to Information and Secrecy Act, which Chapter 36 Section 5 and 6 of the Code refers to. ${ }^{32}$ For example financial secrets within the government are protected as well as secrets in favour for the country's safety. Persons, who may not provide such information, may not be heard as witness concerning that information without the permission by the authority in the activity of which the information has been obtained.

If information subject to secrecy is to be provided or adduced at a court hearing, the court may hold a hearing behind closed doors; see Chapter 5 Section 1 second paragraph of the Code.

The court would, according to Chapter 36 Section 6 second paragraph of the Code, accept if a CEO, or such like, would refuse to testify about a certain fact with regard to business secret, if there is no specific reason to question the claim. The witness would though risk to be held responsible for perjury if such a claim is proved to be incorrect. ${ }^{33}$

There would be no difference if such a company is a holder of concession or public service as long as the refusal regards a disclosure of a trade secret. The type of business can affect how the term "trade secret" is defined. Regarding a public law entity, the definition of the term is more limited.

${ }^{32}$ Offentlighets- och sekretesslagen (2009:400). The contents of the act is briefly described in English in the brochure Public Access to Information and Secrecy Act - Information concerning public access to information and secrecy legislation, etc., Revised edition, Ministry of Justice, 2009.

${ }^{33}$ NJA II 1943 p. 472 and NJA II 1948 p. 444. 
If a state official refuses to testify about a certain fact, claiming that it represents a state secret, the court will, as discussed above, accept the claim if there is no reason to doubt it. The court would consider Chapter 36 Section 5 first paragraph of the Code where it refers to secrecy for foreign affairs and secrecy for state finance. To be noted is the responsibility for perjury, which applies. The witness is therefore responsible for the claim to be correct.

If a journalist would refuse to testify about his sources, the court would accept the claim according to Chapter 36 Section 5 sixth paragraph of the Code. The statement refers to Chapter 3 Section 3 the Freedom of the Press Act $^{34}$ and also, depending on which kind of journalism it regards, Chapter 2 Section 3 in the Fundamental Law on Freedom of Expression. $^{35}$

There are interests that may override this privilege according to what is stated in the Freedom of the Press Act and the Fundamental Law on Freedom of Expression, for example in order to investigate crimes regarding high treason, espionage, etc. According to Chapter 2 Section 3 the Fundamental Law on Freedom of Expression, the court can also make a suitability assessment in the specific case, considering the interests at stake. Parties can contest such excuse on the same grounds as mentioned above.

Regarding to Chapter 36 Section 5 first paragraph of the Code, a priest may claim that he is covered by the secrecy of confession. That is an absolute principle and cannot be out-balanced, but parties can contest such an excuse on the same grounds as discussed above.

The court would accept a medical doctor's refusal to testify about certain facts regarding his patient, according to Chapter 36 Section 5 second paragraph of the Code. The principle can be out-balanced according to Chapter 36 Section 4 fourth paragraph of the Code, which refers to Chapter 10 Section 21 in The Public Access to Information and Secrecy Act and concerns crimes of certain seriousness, for example murder. Parties can contest such an excuse on the same grounds as discussed above.

An advocate or the advocate's counsel can refuse to testify about certain facts regarding his client according to Chapter 36 Section 5 second and third paragraph of the Code. This principle can be out-balanced according to Chapter 36 Section 5 fourth paragraph of the Code. To be noted is that a defence counsel and advocates have a wider power to refuse to testify than other counsels. Parties can contest such excuse on the same grounds as discussed above.

Other professionals who can rely upon the same privilege are the ones stated in Chapter 36 Section 5 third paragraph of the Code, which are attorneys, counsels for the defence and counsels for an injured party.

\footnotetext{
${ }^{34}$ Tryckfrihetsförordningen (1949:105).

35 Yttrandefrihetsgrundlagen (1991:1469).
} 
It should be noted that Sweden does not have an advocate monopoly. Hence also nonprofessionals have a right to appear as counsels in the court.

According to Chapter 36 Section 21 of the Code, a witness may be forced to take an oath as the statement follows: "If a witness, without a valid excuse, refuses to take an oath, to testify, to answer a question, or to obey an order pursuant to [Chapter 36] Section 8 , the court shall order the witness to perform his duty under penalty of fine, and, if the witness persists in his refusal, under penalty of detention."

A witness can refuse to testify under oath, according to Chapter 36 Section 13 if the witness is under the age of fifteen years or if the witness is mentally disturbed and therefore found to lack the required insight in the importance of the oath. If the refusal is not stated as accepted by law, the Court may, according to Chapter 36 Section 21, "order the witness to perform his duty under penalty of fine, and, if the witness persists in his refusal, under penalty of detention."

Regarding civil cases, the judge's powers and duties in the process of questioning are regulated in for example Chapter 36 Section 17 of the Code:

A witness examination shall be opened by the party who has invoked the witness unless the court directs otherwise. At the beginning of the examination the witness shall have an opportunity to give his testimony in a continuous sequence all by himself or, if necessary, with the support of questions.

Subsequently, the opposing party shall be afforded an opportunity to hear the witness. If the opposing party is not present or if it is required by another cause, the court should conduct this part of the examination.

Afterwards the court and the parties may put additional questions to the witness. The party who invoked the examination ought to get the first opportunity to do so.

If none of, or both, parties have invoked the testimony, the court shall open the examination, unless it is more appropriate that one of the parties opens it.

Questions inviting to a specific answer by their content or form or by the way in which they are presented may not be put unless, when examining pursuant to paragraph 2, it is required in order to investigate to which extent the witness' statement corresponds with the real course of the event. The court shall reject questions that are manifestly irrelevant to the matter at issue, confusing, or otherwise inappropriate.

In Chapter 43 Section 4 the Code, the judge's direction of proceedings is stated:

The court is responsible for the orderly and systematic progress of the proceeding. The court may direct that separate issues or parts of the case shall be 
taken up individually or that other departures shall be taken from the sequence prescribed by Sections 7 through 9 .

The court shall also make certain that the case is investigated according to its nature and that irrelevant matters are not presented. Through questions and observations the court shall attempt to remedy any unclear and incomplete statement.

Regarding the delivering and the opposing party's powers and duties in the process of questioning, those are regulated in Chapter 36 Section 17, especially the last paragraph where it is stated: "Questions inviting to a specific answer by their content or form or by the way in which they are presented may not be put unless, when examining pursuant to paragraph 2 [cross examination], it is required in order to investigate to which extent the witness' statement corresponds with the real course of the event. The court shall reject questions that are manifestly irrelevant to the matter at issue, confusing, or otherwise inappropriate."

There is a general request for witnesses to produce oral testimony. The conditions to apply a written testimony is stated in Chapter 35 Section 14 second paragraph and Chapter 35 Section 14 third paragraph of the Code, regarding sound and picture recording. There is therefore a possibility to have a private examination of a witness. Expert witnesses shall, as a main rule, produce a written testimony according to Chapter 40 Section 7 and Chapter 40 Section 8 of the Code.

\subsection{Cross Examination in Contradiction}

The Swedish system applies cross-examination according to Chapter 36 Section 17 of the Code:

A witness examination shall be opened by the party who has invoked the witness unless the court directs otherwise. At the beginning of the examination the witness shall have an opportunity to give his testimony in a continuous sequence all by himself or, if necessary, with the support of questions.

Subsequently, the opposing party shall be afforded an opportunity to hear the witness. If the opposing party is not present or if it is required by another cause, the court should conduct this part of the examination.

Afterwards the court and the parties may put additional questions to the witness. The party who invoked the examination ought to get the first opportunity to do so.

If none of, or both, parties have invoked the testimony, the court shall open the examination, unless it is more appropriate that one of the parties opens it.

Questions inviting to a specific answer by their content or form or by the way in which they are presented may not be put unless, when examining pursuant to paragraph 2 , it is 
required in order to investigate to which extent the witness' statement corresponds with the real course of the event. The court shall reject questions that are manifestly irrelevant to the matter at issue, confusing, or otherwise inappropriate.

\section{$7 \quad$ Taking of Evidence}

\subsection{Sequence in Which Evidence has to be Taken}

There is a mandatory sequence during the main hearing in which the evidence has to be taken, see Chapter 46 Section 6 paragraph 2 of the Code, where it is stated:

Hereinafter [at the main hearing] the aggrieved person and the defendant shall be examined and other evidence be presented. The examination of the aggrieved person and the defendant shall occur prior to the taking evidence of witnesses concerning the circumstance that the examination concerns.

The order can however be waived according to Chapter 46 Section 4 first paragraph of the Code where it is stated:

The court is responsible for the orderly and systematic progress of the proceedings. The court may direct that separate issues or parts of the case shall be taken up individually or other departures shall be taken from the sequence prescribed by Sections 6, 9 and 10

\subsection{Responsibility for Bringing the Evidence in Court}

Witnesses and experts are requested by the court. This is not explicitly stated in the Code but can be interpreted from Chapter 36 Section 7 of the Code, Chapter 40 Section 8 of the Code and Chapter 9 Section 7 of the Code. It is there regulated that absence of a witness or an expert can result in a fine, which only the court can impose.

\subsection{Taking of Evidence}

The taking of evidence takes place during the main hearing, as a general rule, according to Chapter 35 Section 8 of the Code where it is stated:

If a main hearing is held, the evidence shall be taken at that hearing unless, in accordance with special provisions, the evidence may be taken outside the main hearing. If a main hearing is not held, or if evidence else shall be taken outside main hearing, the evidence may be taken at the same court or at another court.

The court may, according to Chapter 42 Section 15 and Section 15 a, issue an order of preclusion regarding evidence. The consequence for the party is preclusion; see 1.1-2 above. 
Decisions regarding evidence can generally be changed as long as a judgment has not been issued, according to Chapter 46 Section 17 of the Code, where it is regulated that permitted supplementations may be done up until the adjudication of the case. That point in time may be regarded as a deadline. As to cases where the matter at issue is amenable to out of court settlement, in the court of appeal a party may invoke in support of his position a circumstances or item of evidence not previously presented, only under certain conditions; see Chapter 50 Section 25 third paragraph of the Code in 1.1 above.

Evidence can be secured according to Chapter 41 of the Code where the taking of evidence for future purpose is regulated.

\subsection{Rejection of an Application to Obtain Evidence}

The Swedish law of civil procedure regulates rejection of evidence according to Chapter 35 Section 7 of the Code. According to the statement, the court may reject evidence, for example if it finds the evidence to be without importance in the case, if an item of evidence offered is unnecessary or evidently should be of no effect.

The court shall justify such refusal, according to Chapter 17 Section 11 first paragraph of the Code where a general obligation for the court to motivate its answer is stated.

There is no time limit regarding such an application. New evidence may be presented also in the higher court, see Chapter 50 Section 25 of the Code and Chapter 55 Section 13 of the Code.

Regarding which extent the party is obligated to specify the evidence, the plaintiff, according to Chapter 42 Section 2 first paragraph (3) of the Code, has to specify in the application for a summons "the means of evidence offered and what shall be proved by each means".

According to Chapter 42 Section 7 first paragraph (4) of the Code, the defendant's answer shall contain "a specification of the means of evidence invoked by the defendant and what he will prove by each means".

One of the objectives of the preparation of the case is, according to Chapter 42 Section 6 second paragraph (3) of the Code to elucidate "which means of evidence shall be brought forward and what will be proved by each means."

No be noted, usually, the evidence is not specified until the end of the preparation prior to the judgment, when it is clear which facts that are contentious. One of the purposes of the preparation is to clarify the contentious facts within the case.

Facts established in another proceeding can be reconsidered. However, assessment in earlier proceedings can have evidential effect. 


\subsection{The Hearing}

As a general rule the evidence is taken at the hearing where the principle of directness applies; see Chapter 17 Section 2 of the Code. The general rule is that only the deciding judge or junior judges at the main hearing can take evidence. This is indirectly stated in the Code as it is stated that all evidence is to be taken at the main hearing.

The evidence can be taken before another person by such evidential taking as stated in Chapter 41 of the Code, preservation of evidence for the future, or by international presentation of evidence. Another court may take for example evidence by witnesses, this according to Chapter 35 Section 10 of the Code. The court shall then present to the court designated to take the evidence a request and in the request briefly state the matter at issue, the evidence to be taken, and the circumstance to be proved.

If the court finds it necessary to complement the investigation, the court may, according to Chapter 46 Section 17 of the Code, decide to take evidence also after the main hearing is concluded. In Chapter 46 Section 17 of the Code it is stated:

If, after the closing of the main hearing, the court finds it necessary to complete the inquiry prior to the determination of the case, a continued or new main hearing may be held pursuant to the rules in this chapter. If the completion is of simple nature, however, the court, after consulting the parties, may decide, in lieu of it, the inquiry to be obtained in some other appropriate way.

The parties have a right to be present when the evidence is being taken. As a starting point, they are also obligated to be present during the taking of evidence. As stated under 7.3 above, the taking of evidence takes place during the main hearing, as a general rule. Chapter 11 Section 5 first paragraph of the Code states that "a party shall appear in person at the main hearing" (in a district court or in a court of appeal), "unless it may be assumed that his presence would not be of any significance for the inquiry." These provisions on the obligation of parties to appear in person also apply to their legal representatives. The consequences of not appearing in person or being absent depend on the nature of the case, and on if it is the plaintiff or the defendant who do not appear; see Chapter 44 of the Code. If both parties fail to appear, the case shall be removed from the court's list. If the matter at issue is amenable to out of court settlement a default judgment might be entered. A party may be directed to appear under penalty of fine, and the court may order that a party should be brought before it in custody either immediately or on a later date. Under certain conditions the court may proceed with the hearing, in spite of non-appearance.

The Swedish legal system does not distinguish between direct and indirect types of evidence; according to older legal traditions such notions do, however, exist, one example being the notion of circumstantial evidence. This is, though, not expressed in law. 
Sound and image transmission (e.g. video link) or sound transmission (e.g. telephone) irrespective of the specific technologic solution used - may be used within the Swedish legal system according to Chapter 5 Section 10 of the Code in order to collect live testimony at distance. This is also possible to do abroad without the cooperation of a local court, if the other state approves.

\subsection{Witnesses}

Regarding the procedure for summons, the witnesses are normally ordered with a fine, according to Chapter 9 Section 7 of the Code.

The parties are not supposed to adduce written statements before the testimony. Written statements are only permitted to be used as evidence if both parties agree on their use and the court consider it not to be manifestly improper according to Chapter 35 Section 14 second paragraph of the Code.

The witness shall swear an oath, according to Chapter 36 Section 11 of the Code. The exceptions from the obligation are stated in Chapter 36 Section 13 where it is regulated that "An oath may not be taken by: 1 . a person under the age of fifteen years; or 2. a person who owing to mental disturbance is found to lack the required insight in the importance of the oath." The witnesses are as a starting point questioned individually, according to Chapter 36 Section 9 second paragraph of the Code.

The approach towards preparations of witnesses is that witnesses may be prepared. The witness is however not obligated to answer questions outside of the hearing. According to the saying "there is no property in witnesses" it is allowed for the adverse party's witness to contact the other side's witness.

\subsection{Expert Witnesses}

It should be noted that expert witnesses are used in a very few cases. There is a fundamental difference made by the court between experts appointed by the parties and experts appointed by the court. It is more common with experts appointed by the parties than experts appointed of the court.

Who shall ask the questions to the expert witness depends on who has appointed the expert witnesses. The court asks the questions to a witness appointed by the curt, see Chapter 40 Section 1 of the Code, but does normally also acquire the parties' opinions. If a party has appointed the expert witness, the questions are asked by that party, according to Chapter 40 Section 19 of the Code.

The same procedure is not being followed when experts and ordinary witnesses are being questioned. The main difference is that an expert witness as a main rule hand in a written statement, the witness shall be heard orally according to Chapter 40 Section 8 "if a party requests it and the examination of the expert is not plainly without importance or if the court otherwise finds it necessary" 
The judge's powers and duties in the process are regulated in Chapter 35 Section 6 of the Code, which states that presentation of evidence is the parties' responsibility, with the exception of matters not amenable to out-of-court settlement. See the more detailed discussion above. When choosing an expert witness, the court must take into account Chapter 40 Section 1-4 of the Code, where for example challengeable and that the parties must have a possibility to be heard about the choice is stated. The expert witnesses' duties are stated in Chapter 40 Section 4 of the Code: "A person who has undertaken such a commission may not avoid its performance without valid excuse."

The delivering party's power and duties in the process of obtaining evidence from an expert is regulated in Chapter 40 of the Code. The party may be heard regarding the choice before an expert witness is appointed, according to Chapter 40 Section 3 of the Code. Regarding an expert witness appointed by the party, the party may independently formulate the questions.

The opposing party has the same right as the delivering party, which has been described above. According to Chapter 40 Section 19 of the Code, the opposing party has a right to question the expert witness during the main hearing. In Chapter 40 Section 19 of the Code it is stated:

As to experts not appointed by the court, but claimed by a party, the provisions in Sections 7 and 8 shall apply to the extent relevant. In other respects, when such an expert is orally examined, the provisions concerning witnesses shall apply; however, if the court finds it suitable, all or part of a written opinion may be read aloud.

The expert witness must always produce a written opinion. In addition, there is an opportunity to hear the witness orally according to Chapter 40 Section 8 of the Code and Chapter 40 Section 19 of the Code. In Chapter 40 Section 8 of the Code it is stated:

An expert who has submitted a written opinion shall also be examined orally if a party requests it and the examination of the expert is not plainly without importance or if the court otherwise finds it necessary. As to an opinion obtained from a central administrative board, an academy, or any other official society, no person who participated in preparing the opinion may be examined orally unless such examination is found unavoidably necessary; if several persons have cooperated in preparing the opinion, only one representative of each view expressed in the opinion may be called.

How the expert witness is being selected depends on the situation. Regarding expert witnesses appointed by the court, it is stated in Chapter 40 Section 1 of the Code:

If, for the determination of an issue the appraisal of which requires special professional knowledge, it is found necessary to call upon an expert, the court may obtain an opinion on the issue from a public authority or officer or from a person specially authorized to furnish opinions on the issue or may commission 
one or more persons known for their integrity and their knowledge of the subject to deliver an opinion.

The parties may, according to Chapter 40 Section 19 of the Code, present a private expert report as evidence.

Regarding the costs for the expert witnesses, the one, either the court or a party, who has appointed the expert witness, also pays the costs. Compensation is to be paid according to Chapter 40 Section 17 of the Code and Chapter 40 Section 18 of the Code. It follows from Chapter 40 Section 17 second paragraph of the Code that "If the matter at issue is amenable to out of court settlement or if the matter concerns liability for an offence not within the domain of public prosecution, the compensation shall be paid by the parties jointly and severally or, if only one of the parties has requested employment of the expert, by that party alone. In all other cases, the compensation shall be paid out of public funds." Chapter 40 Section 18 of the Code states: "An expert is entitled to an advance of his compensation in an amount found reasonable by the court. The advance shall be made as stated in Section 17." The losing party is as a main rule obligated to pay all of the litigation costs, which according to Chapter 18 Section 1 of the Code and Chapter 18 Section 8 of the Code also includes compensation to expert witnesses.

The parties have a right to reject an expert witness and to propose another, however not with a binding force, see Chapter 40 Section 3 of the Code. The court is not bound by the content of written evidence in general, nor is the judge bound by written expert opinions. This applies to both experts appointed by the court, and experts claimed by a party. The assessments of the different kinds of expert opinions are made according to the principle of free evaluation of evidence; see 2.1 above.

\section{Costs and Language}

\subsection{Costs}

What is covered under the term "legal expenses" follows from Chapter 18 Section 8 of the Code which states that "Compensation for litigation costs shall fully cover the costs of preparation for trial and presentation of the action including fees for representation and counsel, to the extent that the costs were reasonably incurred to safeguard the party's interest. Compensation shall also be paid for the time and effort expended by the party by reason of the litigation. Negotiations aimed at settling an issue in dispute that bear directly on the outcome of a party's action are deemed to be measures for the preparation of the trial. Compensation for litigation costs shall also include interest under the Interest $\mathrm{Act}^{36}$, Section 6, running from the date of the court's determination until the date of payment."

The referring party first has to pay for the expenses resulting from taking of evidence. However, after the judgment of the case, it is the losing party who has to pay for the

\footnotetext{
${ }^{36}$ Räntelagen (1975:635).
} 
litigation costs within matters amenable to out-of-court settlement. See for example Chapter 36 Section 24 of the Code regarding the costs for witnesses where it is stated:

A witness is entitled to compensation as stated below.

The compensation of a witness invoked by a private party shall be paid by the party. However, if it is reasonable having regard to the party's economic circumstances, the court may order that the compensation shall be paid out of public funds.

In cases amenable to out of court settlement and in prosecutions for offences that do not fall within the domain of public prosecution, the compensation of witnesses called by the court on its own motion shall be paid by the parties jointly and severally. In other cases, compensation to witnesses shall be paid out of public funds.

Compensation paid by a party shall include reimbursement of necessary costs for travel and maintenance and loss of time in an amount deemed reasonable by the court. Compensation paid out of public funds shall be determined by the court pursuant to regulations issued by the government.

Payment in advance may occur regarding oral evidence, for example costs for witnesses, see Chapter 36 Section 25 of the Code, which also applies to expert witnesses according to Chapter 40 Section 18 of the Code. Payment in advance may also occur when the court ex officio appoints witnesses, see Chapter 36 Section 24 second paragraph of the Code and regarding expert witnesses see Chapter 40 Section 17 of the Code.

The compensation for a witness before a court includes what is stated in Chapter 36 Section 24 third paragraph of the Code:

Compensation paid by a party shall include reimbursement of necessary costs for travel and maintenance and loss of time in an amount deemed reasonable by the court. Compensation paid out of public funds shall be determined by the court pursuant to regulations issued by the government.

The compensation paid out of public funds is regulated in detail; see decree 1982:805 and decree 1973:261. For example it is specified what costs for travel and maintenance and loss of time that may be paid.

Regarding which costs that are to be paid by the requesting court if an expert is appointed, it is stated in Chapter 40 Section 17 that:

When an opinion has been submitted by an authority, officer, or a person specially authorized to furnish opinions, compensation shall be paid only to the extent special provisions so prescribe. Any other expert is entitled to 
compensation for costs accruing in the execution of his duties and for expenditure of his effort and time lost in an amount found reasonable by the court.

If the matter at issue is amenable to out of court settlement or if the matter concerns liability for an offence not within the domain of public prosecution, the compensation shall be paid by the parties.

The costs, which are to be paid by the requesting court if an interpreter is appointed in the proceedings, depends on the circumstances. If a party or a witness does not understand or speak Swedish and the remaining conditions in Chapter 5 Section 6 of the Code are fulfilled, the costs will be paid by the court according to Chapter 5 Section 8 of the Code.

Regulation 1206/2001 is complemented by the Swedish law (2003:493). ${ }^{37}$ There is no specific procedure regarding the costs for the Swedish court. The parties may be imposed to pay the litigation costs.

The costs for the interpretation are to be reimbursed later; see above.

\subsection{Language and Translation}

The court will appoint an appropriate interpreter, who according to Chapter 5 Section 6 of the Code not shall be challengeable. The Swedish system gives credential to court interpreters, but also other interpreters who are considered suitable may be appointed.

Documents within the proceeding are translated when necessary, according to Chapter 33 Section 9 of the Code. A sworn interpreter does not have to be consulted.

The interpreter can be appointed if a witness is incapable to understand or speak Swedish, according to Chapter 5 Section 6 first paragraph of the Code. The witness does not dispose over the question to appoint an interpreter, since the interpreter is appointed to assist the court.

The court covers the costs of the interpretation according to Chapter 5 Section 8 of the Cost.

If the court is taking evidence through a videoconference, the same considerations will be made as if the Court would take evidence directly at the hearing.

There is no certain protocol for interpretation of substantive legal rules. Neither is there any certain protocol for interpretation of procedural rules The Government Office presents some Swedish statues translated; see the links http://www.government.se/sb/d/3288 and www.government.se/sb/d/3288/a/19568.

\footnotetext{
${ }^{37}$ Lagen (2003:493) om EG:s förordning om bevisupptagning i mål och ärenden av civil eller kommersiell natur.
} 
However, the texts are not official translations, and some of them are somewhat out-ofdate.

\section{Unlawful Evidence}

\subsection{Distinction Between "Illegally Obtained Evidence" and "Illegal Evidence"}

In the Swedish civil and commercial litigation system there is, as a starting point, no distinction between illegally obtained evidence and illegal evidence. Under what circumstances evidence may be rejected by the court follows from Chapter 35 Section 7 of the Code. From the statement follows that if the court finds that a circumstance that a party offers to prove is without importance in the case, or that an item of evidence offered is unnecessary or evidently should be of no effect, the court shall reject that proof. The court shall also reject an item of evidence offered if the evidence can be presented in another way with considerably less trouble or costs.

According to a far-reaching principle of free production of evidence and principle of free assessment of evidence, all means of evidence are allowed if it may have an effect on the evidential value. The limitations regarding the right to a fair trial are stated in Article 6 of the ECHR, and Chapter 2 Section 19 the Instrument of Government ${ }^{38}$ where it is stated: "No act of law or other provision may be adopted which contravenes Sweden's undertakings under the European Convention for the Protection of Human Rights and Fundamental Freedoms." The ECHR is now an integrated part of the Swedish legal system according to the law about the European Convention on Human Rights and Fundamental Freedoms. ${ }^{39}$ The right to a fair trial is also clearly expressed in Chapter 2 Section 11 second paragraph the Instrument of Government, where it is stated:

No court of law may be established on account of an act already committed, or for a particular dispute or otherwise for a particular case. Legal proceedings are to be carried out fairly and within a reasonable period of time. Proceedings in courts of law shall be open to the public.

The article was added directly inspired by Article 6 of the ECHR through the latest reform of the constitution in 2010.

Neither has the Swedish system a normative solution establishing the illegality of mean of obtaining evidence as such. Certain actions may be illegal on other grounds, e.g. theft.

\footnotetext{
${ }^{38}$ Regeringsformen (1974:152).

39 Lag (1994:1219) om den europeiska konventionen angående skydd för de mänskliga rättigheterna och de grundläggande friheterna.
} 


\section{The Report about the Regulation No 1206/2001}

Council Regulation (EC) No 1206/2001 on the taking of evidence in civil or commercial matter, Article 21 on relationship with existing or future agreements or arrangements between Member States, states:

1. This Regulation shall, in relation to matters to which it applies, prevail over other provisions contained in bilateral or multilateral agreements or arrangements concluded by the Member States and in particular the Hague Convention of 1 March 1954 on Civil Procedure and the Hague Convention of 18 March 1970 on the Taking of Evidence Abroad in Civil or Commercial Matters, in relations between the Member States party thereto.

2. This Regulation shall not preclude Member States from maintaining or concluding agreements or arrangements between two or more of them to further facilitate the taking of evidence, provided that they are compatible with this Regulation.

3. Member States shall send to the Commission:

(a) by 1 July 2003, a copy of the agreements or arrangements maintained between the Member States referred to in paragraph 2;

(b) a copy of the agreements or arrangements concluded between the Member States referred to in paragraph 2 as well as drafts of such agreements or arrangements which they intend to adopt; and

(c) any denunciation of, or amendments to, these agreements or arrangements.

In the Study on the application of Council Regulation (EC) No 1206/2001 on the taking of evidence in civil or commercial matter, March 2007, p. 107, it is reported that here are no relevant agreements etc. regarding Sweden. This information is not fully accurate. Apart from some multilateral-agreements that are left out (e.g. The Hague Convention of 1 March 1954 on Civil Procedure and the Convention of 26 April 1974 between Sweden, Denmark, Finland, Iceland and Norway) there is an also bilateral convention of 1930, mentioned by The United Kingdom. The reported treaties do not seem to be more favourable in any other way than the possibility to use Swedish language among the Nordic states.

\section{Table of Authorities}

The Ministry of Justice is the competent authority referred to in Article 3(3) according to "Tillkännagivande (2003:483) om EG:s förordning om bevisupptagning i mål och ärenden av civil eller kommersiell natur". The most relevant statute is the Code, for which it exists a translation from year 1998 (see http://www.government.se/sb/d/390/a/1540). Relevant cases are for example a decision 
from the Svea Court of Appeal on September 26, 2008 in case no. 4919-07. The court concluded that evidence could be obtained applying Regulation 1206/2001, when witnesses residing in England refused to go to the Swedish court to testify (and could not be forced to attend), in spite of Chapter 36 Section 20 first paragraph of the Code, which states: "An examination of a witness may take place outside main hearing [- - - ] if it is not possible for the witness to attend the main hearing". 40

${ }^{40}$ The Supreme Court relied on an expert witness statement by the former chief justice of the court Torkel Gregow, who had published an article based on his responsum, Gregow (2008). 
Evidence in Civil Law - Sweden

E. Bylander

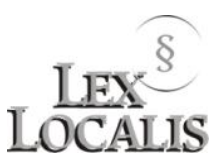

\section{Part II - Synoptical Presentation}

\section{$1 \quad$ Synoptic Tables}

\subsection{Ordinary/Common Civil Procedure Timeline}

When referred to legal statues in the table, the Code (if nothing else mentioned) is referred to. To be noted, generally, a duty corresponds towards a right.

Regarding the consequences that may occur if the court sets aside its duties, it will be regarded as a trial error (in Swedish rättegångsfel). If the court's wrongful actions have had an effect on the outcome of the case, it may result in a quash of the judgment, if the case is appealed to a higher court.

\begin{tabular}{|c|c|c|c|}
\hline $\begin{array}{l}\text { Phase } \\
\#\end{array}$ & $\begin{array}{l}\text { Name of the Phase } \\
\text { Name of the Phase in } \\
\text { National Language }\end{array}$ & $\begin{array}{l}\text { Responsible } \\
\text { Subject }\end{array}$ & $\begin{array}{l}\text { Duties of the Responsible Subject } \\
\text { (related only to Evidence) and } \\
\text { Consequences of their Breach }\end{array}$ \\
\hline 1 & $\begin{array}{l}\text { Application for a } \\
\text { summons } \\
\text { Stämningsansökan }\end{array}$ & $\begin{array}{l}\text { Plaintiff } \\
\text { Käranden }\end{array}$ & $\begin{array}{l}\text { For duties see Chapter } 42 \text { Section } 2 \text { first } \\
\text { paragraph (3), and fourth paragraph. } \\
\text { The consequence is an order to rectify the } \\
\text { defect according to Chapter } 42 \text { Section } 3 \\
\text { or dismissal according to Chapter } 42 \\
\text { Section } 4 \text {. }\end{array}$ \\
\hline 2 & $\begin{array}{l}\text { Issue a writ of } \\
\text { summons } \\
\text { Utfärdande av } \\
\text { stämning }\end{array}$ & $\begin{array}{l}\text { The court } \\
\text { Domstolen }\end{array}$ & $\begin{array}{l}\text { The court is responsible to issue a writ of } \\
\text { summons and to serve a summons to the } \\
\text { defendant according to Chapter } 42 \\
\text { Section } 5 \text {. }\end{array}$ \\
\hline 3 & $\begin{array}{l}\text { Preparation according } \\
\text { to Chapter } 42 \text { Section } \\
6-9 . \\
\text { Förberedelse }\end{array}$ & $\begin{array}{l}\text { The court and } \\
\text { the parties } \\
\text { Domstolen } \\
\text { och parterna }\end{array}$ & $\begin{array}{l}\text { According to Chapter } 42 \text { Section } 6 \text { to } 9 \\
\text { shall, for example, as a main rule a } \\
\text { preparation take place if a summons has } \\
\text { been issued. } \\
\text { The consequence that may occur if a } \\
\text { party later on presents new facts is the } \\
\text { effect of preclusion according to Chapter }\end{array}$ \\
\hline
\end{tabular}




\begin{tabular}{|c|c|c|c|}
\hline & & & 43 Section 10. \\
\hline $3 a$ & $\begin{array}{l}\text { Defendants stating his } \\
\text { defence } \\
\text { Avgivande av } \\
\text { svaromål }\end{array}$ & $\begin{array}{l}\text { The defendant } \\
\text { Svaranden }\end{array}$ & $\begin{array}{l}\text { Chapter } 42 \text { Section } 17 \text { states that the } \\
\text { defendant immediately shall state his } \\
\text { answer. }\end{array}$ \\
\hline $3 b$ & $\begin{array}{l}\text { Session as a main rule } \\
\text { Sammanträde som } \\
\text { huvudregel }\end{array}$ & $\begin{array}{l}\text { The court and } \\
\text { the parties. } \\
\text { Rätten och } \\
\text { parterna }\end{array}$ & $\begin{array}{l}\text { According to Chapter } 42 \text { Section } 9 \text {, the } \\
\text { court shall direct the parties to attend a } \\
\text { session. The parties shall appear at the } \\
\text { session according to Chapter } 44 \text {. }\end{array}$ \\
\hline $3 \mathrm{c}$ & $\begin{array}{l}\text { Establish a list or } \\
\text { compilation. } \\
\text { Upprätta en } \\
\text { förteckning eller } \\
\text { sammanställning }\end{array}$ & $\begin{array}{l}\text { The court } \\
\text { Domstolen }\end{array}$ & $\begin{array}{l}\text { The court shall if it is beneficial to the } \\
\text { proceeding, according to Chapter } 42 \\
\text { Section } 14 \text { and Section } 16 \text {, establish a } \\
\text { specification of the relevant issues. } \\
\text { The parties have duty to prepare the } \\
\text { matter, possibly hand in material and } \\
\text { comment the material. - Regarding the } \\
\text { consequences, see } 3 \mathrm{~d} \text { below. }\end{array}$ \\
\hline $3 d$ & $\begin{array}{l}\text { Order of preclusion } \\
\text { Preklusionsföre- } \\
\text { läggande }\end{array}$ & $\begin{array}{l}\text { The } \\
\text { court/party } \\
\text { /the parties } \\
\text { Domstolen/ } \\
\text { part/parter }\end{array}$ & $\begin{array}{l}\text { The court may, according to Chapter } 42 \\
\text { Section } 15 \text { and Section } 15 \text { a, issue an } \\
\text { order of preclusion. The consequence for } \\
\text { the party is preclusion if no valid excuse. }\end{array}$ \\
\hline 4 & $\begin{array}{l}\text { Conciliation and } \\
\text { mediation } \\
\text { Förlikning och } \\
\text { medling }\end{array}$ & $\begin{array}{l}\text { The court } \\
\text { Domstolen }\end{array}$ & $\begin{array}{l}\text { The duty for the court to act in order for } \\
\text { the parties to reach a settlement is stated } \\
\text { in Chapter } 42 \text { Section } 17 \text {. }\end{array}$ \\
\hline 5 & $\begin{array}{l}\text { Determination of a } \\
\text { case without a main } \\
\text { hearing } \\
\text { Avgörande utan } \\
\text { huvudförhandling }\end{array}$ & $\begin{array}{l}\text { The court and } \\
\text { the parties } \\
\text { Domstolen } \\
\text { och parterna }\end{array}$ & $\begin{array}{l}\text { According to Chapter } 42 \text { Section } 18 \text {, the } \\
\text { court may dispose a case without a main } \\
\text { hearing if it is not disposed by judgment. } \\
\text { The parties' duty in such situation, is to } \\
\text { conclude their claim. }\end{array}$ \\
\hline 6 & $\begin{array}{l}\text { Main hearing } \\
\text { Huvudförhandling }\end{array}$ & $\begin{array}{l}\text { The court and } \\
\text { the parties } \\
\text { Domstolen } \\
\text { och parterna }\end{array}$ & According to Chapter 43. \\
\hline $6 a$ & $\begin{array}{l}\text { Assessement of } \\
\text { impediment towards a } \\
\text { main hearing } \\
\text { Prövning av hinder } \\
\text { mot huvudförhandling }\end{array}$ & $\begin{array}{l}\text { The court } \\
\text { Domstolen }\end{array}$ & According to Chapter 43 Section 1-3. \\
\hline $6 b$ & $\begin{array}{l}\text { Order and } \\
\text { investigation } \\
\text { Ordning och } \\
\text { utredning }\end{array}$ & $\begin{array}{l}\text { The court and } \\
\text { the parties. } \\
\text { Domstolen } \\
\text { och parterna }\end{array}$ & $\begin{array}{l}\text { The court is, according to Chapter } 43 \\
\text { Section } 4 \text {, "responsible for the orderly } \\
\text { and systematic progress of the } \\
\text { proceeding. The court may direct that } \\
\text { separate issues or parts of the case shall } \\
\text { be taken up individually or that other }\end{array}$ \\
\hline
\end{tabular}




\begin{tabular}{|c|c|c|c|}
\hline & & & $\begin{array}{l}\text { departures shall be taken from the } \\
\text { sequence prescribed by Sections } 7 \\
\text { through } 9 \text {. } \\
\text { The court shall also make certain that the } \\
\text { case is investigated according to its nature } \\
\text { and that irrelevant matters are not } \\
\text { presented. } \\
\text { Through questions and obser-vations the } \\
\text { court shall attempt to remedy any unclear } \\
\text { and income-plete statement." } \\
\text { The parties' duties appear from Chapter } \\
43 \text { Section } 6 \text {, which may have } \\
\text { consequences for the evi-dential } \\
\text { evaluation according to Chapter } 35 \\
\text { Section } 4 \text {. }\end{array}$ \\
\hline $6 c$ & $\begin{array}{l}\text { Claims } \\
\text { Yrkanden }\end{array}$ & $\begin{array}{l}\text { The parties } \\
\text { Parterna }\end{array}$ & According to Chapter 43 Section 7. \\
\hline $6 \mathrm{~d}$ & $\begin{array}{l}\text { Development of the } \\
\text { claim } \\
\text { Utveckling av talan }\end{array}$ & $\begin{array}{l}\text { The parties } \\
\text { Parterna }\end{array}$ & $\begin{array}{l}\text { The duty is stated in Chapter } 43 \text { Section } 7 \\
\text { second paragraph and the party's } \\
\text { behaviour may have consequences for } \\
\text { evidentiary value according to Chapter } 35 \\
\text { Section } 4 \text {. }\end{array}$ \\
\hline $6 e$ & $\begin{array}{l}\text { Presentation of } \\
\text { evidence } \\
\text { Framläggande av } \\
\text { bevisning }\end{array}$ & $\begin{array}{l}\text { The parties; } \\
\text { exceptionally } \\
\text { the court } \\
\text { Parterna och } \\
\text { undantagsvis } \\
\text { rätten }\end{array}$ & $\begin{array}{l}\text { The parties' duty to present the evidence } \\
\text { is stated in Chapter } 43 \text { Section } 8 \text {. See also } \\
\text { Chapter } 43 \text { Section } 7 \text { third paragraph. } \\
\text { The court may, as an exception in matters } \\
\text { not amenable to out-of-court settlement, } \\
\text { present evidence. } \\
\text { The consequences that may occur of the } \\
\text { parties breach are effects on the evidential } \\
\text { evaluation. }\end{array}$ \\
\hline $6 f$ & $\begin{array}{l}\text { Closing arguments } \\
\text { Slutanföranden }\end{array}$ & $\begin{array}{l}\text { The parties } \\
\text { Parterna }\end{array}$ & $\begin{array}{l}\text { The closing arguments according to } \\
\text { Chapter } 43 \text { Section } 9 \text { are optional. }\end{array}$ \\
\hline 7 & $\begin{array}{l}\text { Continued or new } \\
\text { main hearing } \\
\text { Fortsatt eller ny } \\
\text { huvudförhandling }\end{array}$ & $\begin{array}{l}\text { The parties } \\
\text { and the court } \\
\text { Parterna och } \\
\text { domstolen }\end{array}$ & $\begin{array}{l}\text { The duties are stated in Chapter } 43 \\
\text { Section } 12 \text { and } 13 .\end{array}$ \\
\hline 8 & $\begin{array}{l}\text { Deliberation } \\
\text { Överläggning }\end{array}$ & $\begin{array}{l}\text { The court } \\
\text { Domstolen }\end{array}$ & $\begin{array}{l}\text { The court shall meet to deliberate before } \\
\text { the judgment, according to Chapter } 17 \\
\text { Section } 9 \text { and in Chapter } 16 \text { the rules } \\
\text { regarding voting are stated. }\end{array}$ \\
\hline 9 & $\begin{array}{l}\text { Supplementing } \\
\text { Komplettering }\end{array}$ & $\begin{array}{l}\text { The court } \\
\text { Domstolen }\end{array}$ & $\begin{array}{l}\text { The court shall supplement the case if it } \\
\text { finds it necessary prior to the } \\
\text { determination according to Chapter } 43 \\
\text { Section } 14 \text {. }\end{array}$ \\
\hline 10 & $\begin{array}{l}\text { Rendering of } \\
\text { judgment and } \\
\text { documentation. } \\
\text { Beslutande av dom } \\
\text { och dokumentation }\end{array}$ & $\begin{array}{l}\text { The court } \\
\text { Domstolen }\end{array}$ & According to Chapter 17 Section 9. \\
\hline
\end{tabular}




\begin{tabular}{|c|c|c|c|}
\hline 11 & $\begin{array}{l}\text { Pronouncement of } \\
\text { judgment } \\
\text { Meddelande av dom }\end{array}$ & $\begin{array}{l}\text { The court } \\
\text { Domstolen }\end{array}$ & According to Chapter 17 Section 9. \\
\hline 12 & $\begin{array}{l}\text { Rectification } \\
\text { Rättelse }\end{array}$ & $\begin{array}{l}\text { The court } \\
\text { Domstolen }\end{array}$ & $\begin{array}{l}\text { According to Chapter } 17 \text { Section } 15 \text {, the } \\
\text { parties have, though, some impact of the } \\
\text { decision. }\end{array}$ \\
\hline 13 & $\begin{array}{l}\text { Appeal } \\
\text { Överklagande }\end{array}$ & $\begin{array}{l}\text { The parties } \\
\text { Parterna }\end{array}$ & According to Chapter 49. \\
\hline 14 & $\begin{array}{l}\text { Adjudication of } \\
\text { dispensation review to } \\
\text { the Court of Appeal } \\
\text { Prövningstillstånds- } \\
\text { prövning } i \text { hovrätt }\end{array}$ & $\begin{array}{l}\text { The court } \\
\text { Domstolen }\end{array}$ & $\begin{array}{l}\text { According to Chapter } 49 \text { Section } 12 \text { to } \\
15 .\end{array}$ \\
\hline 15 & $\begin{array}{l}\text { Proceeding in the } \\
\text { Court of Appeal } \\
\text { Hovrättsförfarande }\end{array}$ & $\begin{array}{l}\text { See } 1-13 \\
\text { above. }\end{array}$ & According to Chapter 50. \\
\hline 16 & $\begin{array}{l}\text { Adjudication of } \\
\text { dispensation review to } \\
\text { The Supreme Court } \\
\text { Prövningstillstånds- } \\
\text { prövning i Högsta } \\
\text { domstolen }\end{array}$ & $\begin{array}{l}\text { See } 1-13 \\
\text { above. }\end{array}$ & According to Chapter 54. \\
\hline 17 & $\begin{array}{l}\text { Proceeding in the } \\
\text { Supreme Court } \\
\text { Förfarande } i \text { Högsta } \\
\text { Domstolen }\end{array}$ & $\begin{array}{l}\text { See } 1-13 \\
\text { above. }\end{array}$ & According to Chapter 55. \\
\hline
\end{tabular}

\subsection{Functional Comparison}

\begin{tabular}{|c|c|c|c|c|}
\hline $\begin{array}{l}\text { Means } \\
\text { of Taking } \\
\text { Evidence }\end{array}$ & National Law & $\begin{array}{l}\text { Bilateral } \\
\text { Treaties }\end{array}$ & $\begin{array}{l}\text { Multilateral } \\
\text { Treaties }\end{array}$ & $\begin{array}{l}\text { Regulation } \\
1206 / 2001\end{array}$ \\
\hline $\begin{array}{c}\text { Hearing of } \\
\text { Witnesses by } \\
\text { Mutual Legal } \\
\text { Assistance } \\
\text { (Legal Aid) }\end{array}$ & $\begin{array}{l}\text { Possible according to } \\
\text { Chapter } 35 \text { Section } 10 \\
\text { of the Code: } \\
\text { "If the court orders } \\
\text { evidence to be taken by } \\
\text { another court within the } \\
\text { Realm, the court shall } \\
\text { present accordingly to } \\
\text { the court designated to } \\
\text { take the evidence a } \\
\text { request and in the } \\
\text { request briefly state the } \\
\text { matter at issue, the } \\
\text { evidence to be taken, } \\
\text { and the circumstance to } \\
\text { be proved. The case file } \\
\text { shall be attached to the } \\
\text { request if transmission }\end{array}$ & Not applicable & $\begin{array}{l}\text { Between the } \\
\text { Convention of } 26 \\
\text { April } 1974 \\
\text { between Sweden, } \\
\text { Denmark, } \\
\text { Finland, Iceland } \\
\text { and Norway and } \\
\text { the Swedish law, } \\
\text { there is no } \\
\text { distinctive } \\
\text { difference. See } \\
\text { for example Lag } \\
\text { (1974:752) om } \\
\text { nordisk } \\
\text { vittnesplikt m.m. }\end{array}$ & $\begin{array}{l}\text { The formalities } \\
\text { differ, according } \\
\text { to Article } 4 \text { and } \\
5 \text {, there is a form. } \\
\text { This includes } \\
\text { transmission of } \\
\text { request, } \\
\text { substance and } \\
\text { language. } \\
\text { Otherwise, the } \\
\text { only differences } \\
\text { that may follow } \\
\text { of the national } \\
\text { law in the } \\
\text { member state, } \\
\text { where the } \\
\text { requested court is } \\
\text { situated, see }\end{array}$ \\
\hline
\end{tabular}




\begin{tabular}{|c|c|c|c|c|}
\hline & $\begin{array}{l}\text { of the file is found } \\
\text { appropriate and there is } \\
\text { no impediment to its } \\
\text { dispatch from the } \\
\text { court." }\end{array}$ & & & Article 10.3 \\
\hline $\begin{array}{l}\text { Hearing of } \\
\text { Witnesses by } \\
\text { Video- } \\
\text { conferencing } \\
\text { with Direct } \\
\text { Asking of } \\
\text { Questions }\end{array}$ & $\begin{array}{l}\text { Possible according to } \\
\text { Chapter } 5 \text { Section } 10 \text { of } \\
\text { the Code and Chapter } \\
5 \text { Section } 11 \text { of the } \\
\text { Code. The hearing is } \\
\text { held as if the person is } \\
\text { present. The court will } \\
\text { have the same authority } \\
\text { as if the trial was held } \\
\text { there }\end{array}$ & Not applicable & See above. & $\begin{array}{l}\text { See above and } \\
\text { also Article } 10.4 \text {. }\end{array}$ \\
\hline $\begin{array}{c}\text { Direct Hearing } \\
\text { of Witnesses by } \\
\text { Requesting } \\
\text { Court in } \\
\text { Requested } \\
\text { Country }\end{array}$ & $\begin{array}{l}\text { The court may have a } \\
\text { meeting at another } \\
\text { place; see Chapter } 1 \\
\text { Section } 6 \text { of the Code. } \\
\text { The taking of evidence } \\
\text { will follow the normal } \\
\text { regulation. }\end{array}$ & Not applicable & See above. & $\begin{array}{l}\text { See the first } \\
\text { square. } \\
\text { According to } \\
\text { Article } 12 \text { and } \\
17 .\end{array}$ \\
\hline
\end{tabular}


Evidence in Civil Law - Sweden

E. Bylander

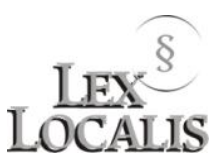

\section{References}

\section{Table of Cases}

Högsta domstolen [The Swedish Supreme Court], NJA 1980 p. 635

Arbetsdomstolen [The Swedish Labour Court], AD 2004 nr 103

Svea hovrätt [Svea Court of Appeal], Decision, September 26, 2008 in case no. 4919-07

\section{Bibliography}

[Swedish Government Official Report] SOU 2012:93 En modernare rättegång II - en uppföljning

Bylander, E., Andersson, T. (2007) Legalisation of Public Documents within the EU Member States, 18/07/2007, http://ec.europa.eu/civiljustice/news/docs/study_ public_docs_sweden.pdf

Edelstam, H. (2001) Offentlighet och sekretess $i$ rättegång: principen om förhandlingsoffentlighet (Stockholm: Norstedts Juridik)

Ekelöf, P.O., Bohman, R. (1992) Rättegång IV (6th edition) (Stockholm: Norstedts Juridik)

Ekelöf, P.O., Edelstam, H. (2002) Rättegång I (8th edition) (Stockholm: Norstedts Juridik)

Ekelöf, P.O., Edelstam, H., Heuman, L. (2009) Rättegång IV (7th Ed.) (Stockholm: Norstedt)

Gregow, T. (2008) Tolkning och tillämpning av äldre bestämmelser på det processuella området, In: Kleineman, J. et al. (Editors): Festskrift till Lars Heuman (Stockholm: Jure Förlag) pp. 209-219

Lindell, B. (1988) Partsautonomins gränser - i dispositiva tvistemål och med särskild inriktning på rättsanvändningen (Uppsala: Iustus förlag)

Lindell, B. (2004) Civil Procedure in Sweden (Uppsala: Iustus förlag)

Lindell, B. (2012) Civilprocessen - Rättegång samt skiljeförfarande och medling (3rd Ed.) (Uppsala: Iustus förlag)

NJA II 1943 = Nytt Juridiskt Arkiv, Avd. II, 1943, P.A. Norstedt \& Söners Förlag, 1944

NJA II 1948 = Nytt Juridiskt Arkiv, Avd. II, 1948, P.A. Norstedt \& Söners Förlag, 1949

Public Access to Information and Secrecy Act - Information concerning public access to information and secrecy legislation, etc., Revised edition, Ministry of Justice, 2009, http://www.regeringen.se/content/1/c6/14/10/34/20793bb4.pdf (2014-08-14)

Study on the application of Council Regulation (EC) No 1206/2001 on the taking of evidence in civil or commercial matter, 2007, http://ec.europa.eu/civiljustice/ publications/docs/final_report_ec_1206_2001_a_09032007.pdf (2015-06-18) 
Swedish statutes in translation - Legal and judicial, Government Offices of Sweden, www.government.se/sb/d/3288/a/19568 (2014-08-14); cf. 11.3 below

Swedish statutes in translation, Government Offices of Sweden, http://www.government.se/sb/d/3288 (2014-08-14); cf. 11.3 below 